\title{
Electrochemical deposition of nickel from aqueous electrolytic baths prepared by dissolution of metallic powder
}

\author{
M. Próchniak ${ }^{1,2}$ (D) M. Grdeń ${ }^{1,2}$ (D)
}

Received: 21 September 2021 / Revised: 21 September 2021 / Accepted: 2 November 2021 / Published online: 11 November 2021 (c) The Author(s) 2021

\begin{abstract}
A new method of preparation of aqueous electrolyte baths for electrochemical deposition of nickel targets for medical accelerators is presented. It starts with fast dissolution of metallic $\mathrm{Ni}$ powder in a $\mathrm{HNO}_{3}$-free solvent. Such obtained raw solution does not require additional treatment aimed to removal nitrates, such as the acid evaporation and Ni salt precipitation-dissolution. It is used directly for preparation of the nickel plating baths after dilution with water, setting up $\mathrm{pH}$ value and after possible addition of $\mathrm{H}_{3} \mathrm{BO}_{3}$. The $\mathrm{pH}$ of the baths ranges from alkaline to acidic. Deposition of $95 \%$ of ca. $50 \mathrm{mg}$ of $\mathrm{Ni}$ dissolved in the bath takes ca. $3.5 \mathrm{~h}$ for the alkaline electrolyte while for the acidic solution it requires ca. $7 \mathrm{~h}$. The $\mathrm{Ni}$ deposits obtained from the acidic bath are physically and chemically more stable and possess smoother and crack-free surfaces as compared to the coatings deposited from the alkaline bath. A method of estimation of concentration of $\mathrm{H}_{2} \mathrm{O}_{2}$ in the electrolytic bath is also proposed.
\end{abstract}

Keywords Medical accelerator targets $\cdot$ Nickel electrodeposition $\cdot$ Nickel dissolution; $\cdot \mathrm{H}_{2} \mathrm{O}_{2}$ determination

\section{Introduction}

Solid nickel targets are frequently used for production of medical radioisotopes by means of nuclear reactions with charged particles from accelerators. Several $\mathrm{Cu}, \mathrm{Co}$ and $\mathrm{Ni}$ radioisotopes of medical importance are produced in reactions of nickel nuclei with high energy protons, deuterons or $\alpha$ particles [1-8]. As an example, ${ }^{64} \mathrm{Cu}$, a very important radioisotope frequently used in positron emission tomography [1,3,9-14] and considered for use in radiotherapy $[10,13,14]$, is produced in medical accelerators using ${ }^{64} \mathrm{Ni}(\mathrm{p}, \mathrm{n}){ }^{64} \mathrm{Cu}$ (mainly), ${ }^{64} \mathrm{Ni}(\mathrm{d}, 2 \mathrm{n}){ }^{64} \mathrm{Cu}$ and ${ }^{61} \mathrm{Ni}(\alpha, \mathrm{p}){ }^{64} \mathrm{Cu}$ reactions [1-3, 11-13, 15-24]. The solid Ni targets used in these processes are typically obtained through electrodeposition on a substrate with a good electronic and heat conductivity, e.g. gold [2, 16-23, 25-27], platinum [15, 28, 29]

M. Próchniak

mmieszkowska@chem.uw.edu.pl

$\triangle$ M. Grdeń

mgrden@chem.uw.edu.pl

1 Faculty of Chemistry, University of Warsaw, Pasteura 1, 02-093 Warsaw, Poland

2 Biological and Chemical Research Centre, University of Warsaw, Żwirki i Wigury 101, 02-089 Warsaw, Poland or copper covered with a protective layer of $\mathrm{Au}$ or $\mathrm{Ag}$ [24, 30]. Unfortunately, some of natural nickel isotopes, which act as targets in production of the medical radioisotopes, are of low natural abundance (from 0.9 to $3.6 \%$ for ${ }^{61} \mathrm{Ni}$, ${ }^{62} \mathrm{Ni}$ and $\left.{ }^{64} \mathrm{Ni}[31]\right)$. Thus, high yield of the nuclear reaction in question is achieved only for a target containing nickel which is highly enriched with the respective isotope. Isotopically enriched nickel, however, is usually very expensive, and, typically, only a very small amount of such material is available for preparation of electrolyte baths. Such bath usually contains from few tens to ca. $120 \mathrm{mg}$ of $\mathrm{Ni}[15,18$, $20,22,23,26,28,32]$. Work with such small amount of the electroactive species leads to serious consequences for the electroplating procedure. Firstly, it is not possible to prepare a bath containing high concentration of the nickel. Reported concentration of isotopically enriched nickel in the baths used for the target deposition typically varies from few tens of millimolar to ca. 0.4 M [33]. This is much less than for typical Watts or sulphamate baths used for industrial nickel plating [34, 35]. Secondly, the amount of Ni dissolved in the bath is calculated in such a way that deposition of all the metal will produce the target layer with a required thickness. Thus, the whole or almost whole (e.g. at least 95\%) amount of the nickel is expected to be deposited. It is a common approach to continue the target electrodeposition until the 
bath becomes colourless (naked eye judgement) [15, 19, 20, $26,28,29,36,37]$. This is in contrast to the industrial plating procedures which do not require complete metal deposition and which left the bath usually only weakly depleted with the metal after completing the deposition.

Although numerous works report electrochemical plating of Ni targets for accelerators [1, 2, 6, 15-28, 30, 36-38], there are some aspects of the electrodeposition process which still need to be improved. Thus, ${ }^{64} \mathrm{Ni}$ and ${ }^{62} \mathrm{Ni}$ are most often available as a metallic powder and there is a need to develop a proper method of its dissolution. Apparently, a concentrated $\mathrm{HNO}_{3}$ is a good medium to dissolve the metallic Ni. Excess of the acid, however, should be removed from the bath after completing the dissolution. Further on, the presence of the nitrates in the electrolyte bath may lead to unwanted precipitation of $\mathrm{Ni}(\mathrm{OH})_{2}$ when $\mathrm{NO}_{3}{ }^{-}$ions undergo cathodic reduction [39-41]. Finally, too high concentration of the nitrates reduces faradaic efficiency of the electrodeposition $[42,43]$. This problem is overcome by evaporation of $\mathrm{HNO}_{3}$ from the liquid containing dissolved nickel and by application of several subsequent steps of dissolution, evaporation and final filtration of such obtained deposit $[2,16,17$, $23,25,27]$. As an alternative, $\mathrm{HNO}_{3}$ can be neutralised with an excess of a hydroxide [20]. This leads to precipitation of $\mathrm{Ni}(\mathrm{OH})_{2}$ which is subjected to repeated procedures of centrifugation and separation from the supernatant [20]. Both these approaches, however, are time consuming and include additional laboratory procedures. Metallic Ni can be also dissolved in concentrated $\mathrm{HCl}$, but again, this step must be followed by additional procedures, such as evaporation and dissolution, aimed to remove the acid [5, 21, 32, 37]. The other problem related to the electrochemical preparation of the targets lies in the fact that the complete deposition of the whole amount of $\mathrm{Ni}$ dissolved in the bath usually requires a very long time, up to $12 \mathrm{~h}[18,23,25], 24 \mathrm{~h}[1,2,15-17$, $20,30,44]$ or even $48 \mathrm{~h}$ or more [2, 22, 38]. Finally, poor quality $\mathrm{Ni}$ deposits, e.g. with cracks or poorly adhered to the substrate, are unacceptable [19, 21, 24, 30, 45].

This manuscript presents preliminary results of works aimed to solve the above-mentioned problems. We report a method of preparation of an aqueous nickel containing electrolyte bath which can be used as a starting point in development of a fast and simple procedure of production of $\mathrm{Ni}$ targets for accelerators. Besides, the method can be used also for other applications, where the plating baths prepared by dissolution of metallic Ni powder are of interest.

\section{Experimental}

All the solutions were prepared using high purity chemicals (Avantor (POCh), Riedel de Haën, Chempur and B\&K) and $18.2 \mathrm{M} \Omega \mathrm{cm}$ water purified in a Millipore system. Ni powder $(99.99 \%$, particle size $<150 \mu \mathrm{m})$ was purchased from Aldrich. The electrodeposition process was carried out in an unstirred bath at room temperature without deoxygenation of the solutions. A two-electrode system was used with a gold foil (99.9\%, Mint of Poland) acting as the working electrode and a platinum wire $(99.99 \%$, Mint of Poland) used as the counter electrode. Gold is one of typical substrates used for electrodeposition of the medical targets. This metal is relatively inert when in contact with hot and concentrated mineral acids used for dissolution of the irradiated target layers. Gold is also relatively convenient to handle after irradiation with the projectiles which passed through the layer of the $\mathrm{Ni}$ deposit. Thus, irradiation of gold with proton beam with energy of up to $15 \mathrm{MeV}$ produces radioisotopes with shorter half-life as compared to platinum subjected to the same treatment $[18,33]$. Further on, the cross-section values (probabilities) of nuclear reactions of such protons with natural Au isotopes are lower than for platinum [18, 33]. Hence, gold is a good choice here.

The electrodeposition was performed in a galvanostatic mode using a Rohde\&Schwarz HMP2020 programmable power supply or a CHInstruments CHI660D electrochemical analyser. Currents of $50-60 \mathrm{~mA} \mathrm{~cm}^{-2}$ (in respect to the geometric area) were applied; an analysis of the current density influence on the deposition process will be reported in a separate communication. UV-Vis spectra of the solutions were recorded with a Shimadzu UV-1800 spectrophotometer while energy-dispersive X-ray fluorescence (ED-XRF) analysis of the deposits was performed using a Shimadzu $800 \mathrm{HS} 2$ system with $50 \mathrm{kV}$ exciting X-ray beam. $\mathrm{pH}$ was measured using a Schott Lab870 pH-meter and a SI Analytics BlueLine electrode. Morphology of the deposits was analysed using a LEO 435VP scanning electron microscope (SEM).

\section{Results and discussion}

\section{Nickel powder dissolution}

Dissolution of Ni powder $(\mathrm{Ni}(0))$ was carried out in absence of $\mathrm{HNO}_{3}$. Mass of a single batch of the Ni powder used for the bath preparation was equal to $50-54 \mathrm{mg}$. Complete deposition of such amount of the metal leads to formation of a layer with a thickness of $112-121 \mu \mathrm{m}$ for the surface area of $0.5 \mathrm{~cm}^{2}$. In order to obtain a reasonably high concentration of $\mathrm{Ni}$ ions in the electrolyte bath, the volume of the solution used for the metal dissolution as well as the volume of the final plating bath should be as low as possible. The powder was dissolved in a solution containing $0.1 \mathrm{ml}$ of $30 \% \mathrm{H}_{2} \mathrm{O}_{2}$ and $0.5 \mathrm{ml}$ of $3 \mathrm{M} \mathrm{H}_{2} \mathrm{SO}_{4}$. The dissolution is a fast and vigorous process which takes less than $5 \mathrm{~min}$ at room temperature. It can be made even faster by heating the mixture up 
to $70-80{ }^{\circ} \mathrm{C}$. When the dissolution does not proceed with a sufficient rate, an additional amount of $\mathrm{H}_{2} \mathrm{O}_{2}$, up to $0.1 \mathrm{ml}$, can be added. Such prepared liquid is referred further in the text as raw solution and constitutes the basis for preparation of the final electrolyte baths.

Application of a mixture containing $\mathrm{H}_{2} \mathrm{O}_{2}$ and a mineral acid $\left(\mathrm{H}_{2} \mathrm{SO}_{4}\right.$ [44, 46-48] or $\mathrm{HCl}$ [5]) to dissolve metallic $\mathrm{Ni}$ has been reported in the earlier literature. Such approach was used for dissolution of powders $[5,44,47,48]$ and crushed electrical circuit boards [46]. This is the first step in preparation of electrolytic baths used for deposition of accelerator targets described in $[5,44,48]$. The procedure presented by us differs in several aspects from those reported by the above-mentioned papers. Thus, in contrast to [5], we use $\mathrm{H}_{2} \mathrm{SO}_{4}$ instead of $\mathrm{HCl}$. The presence of the latter in the electrolytic bath may enhance anodic dissolution of Pt counter electrode $[49,50]$ and may result in extensive $\mathrm{Cl}_{2}$ evolution [51] when the anode is subjected to a strong anodic polarisation. In contrast to [44], we add only a single portion of $\mathrm{H}_{2} \mathrm{O}_{2}$ instead of gradual addition of several batches of the peroxide during the dissolution process. We also use a higher concentration of both $\mathrm{H}_{2} \mathrm{SO}_{4}(2.50 \mathrm{M})$ and $\mathrm{H}_{2} \mathrm{O}_{2}$ $(1.63 \mathrm{M})$ as compared to [44, 46, 47], where the respective concentrations varies from 0.1 to $2 \mathrm{M}$ for the acid and from 0.06 to $0.22 \mathrm{M}$ for the peroxide. Peroxide-to-nickel molar ratio used in the present work is ca. 1.1 which is similar to $1.2-1.3$ reported in $[44,46]$ but less than 3.5 described in [47]. Concentration of the nickel cations in the raw solution prepared by us varies from 1.4 to $1.6 \mathrm{M}$ and is comparable to $1.73 \mathrm{M}$ from [5] but significantly higher than $0.017-0.17 \mathrm{M}$ obtained in [44, 46, 47]. It is important to note that we did not observe significant differences between electroplating from baths prepared from raw solutions when concentrations of $\mathrm{Ni}^{2+}, \mathrm{H}_{2} \mathrm{SO}_{4}$ and $\mathrm{H}_{2} \mathrm{O}_{2}$ were varied within the limits reported above. As compared to $[44,47]$, the procedure described in this paper can be successfully applied at room temperature and dissolves nickel faster. It also allows dissolving higher amount of Ni powder in respect to the volume of the liquid medium as compared to [47], but the presented approach seems to be economically beneficent only when applied to small amounts of the metal. It should be noted that an enhancement in the $\mathrm{Ni}$ powder dissolution can be obtained by adding other than $\mathrm{H}_{2} \mathrm{O}_{2}$ oxidising agent, e.g. $\mathrm{Fe}^{3+}$ [47]. This approach, however, may result in unwanted iron co-deposition when the latter is not removed from the electrolyte bath prior to the electrodeposition.

In the next step, the raw solution is converted into the electrolytic bath. Two of the most often applied Ni electrodeposition baths are the alkaline one containing ammonia $\mathrm{Ni}^{2+}$ complexes ( $\mathrm{pH}$ of 9-11) $[2,15,16,18-20,22,24$, 26-28, 38] and the acidic one, usually containing sulphates (pH of 3-5) [19, 21, 23, 30, 34]. $\mathrm{pH}$ of our raw solution is lower than 0 being too low as for the intended applications. The most obvious way of neutralisation of such type of the solution is by means of addition of a proper amount of a hydroxide. However, gradual neutralisation of the raw solution with aqueous ammonia or alkali metal hydroxide solutions leads to slow precipitation of a green deposit and this process occurs already at $\mathrm{pH}$ lower than ca. 0.3 . The precipitate is dissolved when the $\mathrm{pH}$ is lowered back to the more acidic values. It is also completely dissolved when the $\mathrm{pH}$ is raised above 7 by adding $\mathrm{NH}_{3 \mathrm{aq}}$. The latter solution has a blue colour due to presence of ammonia $\mathrm{Ni}^{2+}$ complexes and can be used for preparation of the alkaline electrolyte bath. When the $\mathrm{pH}$ is decreased back below 7, the precipitate reappears and can be dissolved only after shifting $\mathrm{pH}$ below ca. 0.3. The precipitate in question probably contains nickel hydroxide sulphates, i.e. double salts (or mixed complexes) containing $\mathrm{Ni}(\mathrm{OH})_{2}$ and $\mathrm{NiSO}_{4}$. Generation of these species was reported to take place at $\mathrm{pH}$ of 2 during neutralisation of $\mathrm{NiSO}_{4}$ with $\mathrm{NaOH}$ [52].

Formation of the above-mentioned precipitate has a strong impact on the further treatment of the raw solution. Thus, preparation of the alkaline bath with $\mathrm{pH}$ of 9.2-9.9 is relatively simple and relies on neutralisation of the raw solution with a proper amount of $25 \%$ ammonia solution until a clear liquid free from the precipitate and with required $\mathrm{pH}$ is obtained. Subsequently, distilled water is added to the total volume of 2.0-2.1 ml. More complex is preparation of the acidic bath with $\mathrm{pH}$ of 3-5. Such bath cannot be obtained by neutralisation of the raw solution with $\mathrm{NH}_{3 \text { aq }}$ due to the fact that the above-mentioned $\mathrm{Ni}$-containing precipitate is stable in this $\mathrm{pH}$ range. Therefore, an alternative method of the raw solution neutralisation had to be developed. We found that this task can be successfully completed by addition of sodium or ammonia acetate instead of the hydroxides or $\mathrm{NH}_{3 \mathrm{aq}}$. Solubility of these acetates in water is very high, and they dissolve very fast at room temperature. Addition of the acetates allows to increase $\mathrm{pH}$ up to the values higher than 5. As an example, setting up $\mathrm{pH}$ in the range of 4.1-4.5 requires the addition of $0.128-0.167 \mathrm{~g} \mathrm{ml}^{-1}$ of $\mathrm{CH}_{3} \mathrm{COONa} \cdot 3 \mathrm{H}_{2} \mathrm{O}$. It is worth to note that the presence of the acetates in the electrolytic bath may also facilitate formation of good quality Ni deposits [53]. Addition of the acetates is preceded by dilution of the raw solution with distilled water up to the volume of 2.0-2.1 ml. Boric acid was added to the both the alkaline and the acidic electrolyte giving the final concentration of $0.31-0.34 \mathrm{M} . \mathrm{H}_{3} \mathrm{BO}_{3}$ is known to improve quality of $\mathrm{Ni}$ deposits although the exact mechanism of the acid influence on the nickel electrodeposition is still discussed [33, 54-57]. Thus, $\mathrm{H}_{3} \mathrm{BO}_{3}$ is considered as a hydrogen evolution reaction inhibitor, surface $\mathrm{pH}$ regulator and $\mathrm{Ni}^{2+}$ complexing agent [34, 53-59]. Concentration of the nickel cations in both the alkaline and the acidic bath varies from 0.37 to $0.45 \mathrm{M}$. Apparently, variation of the 


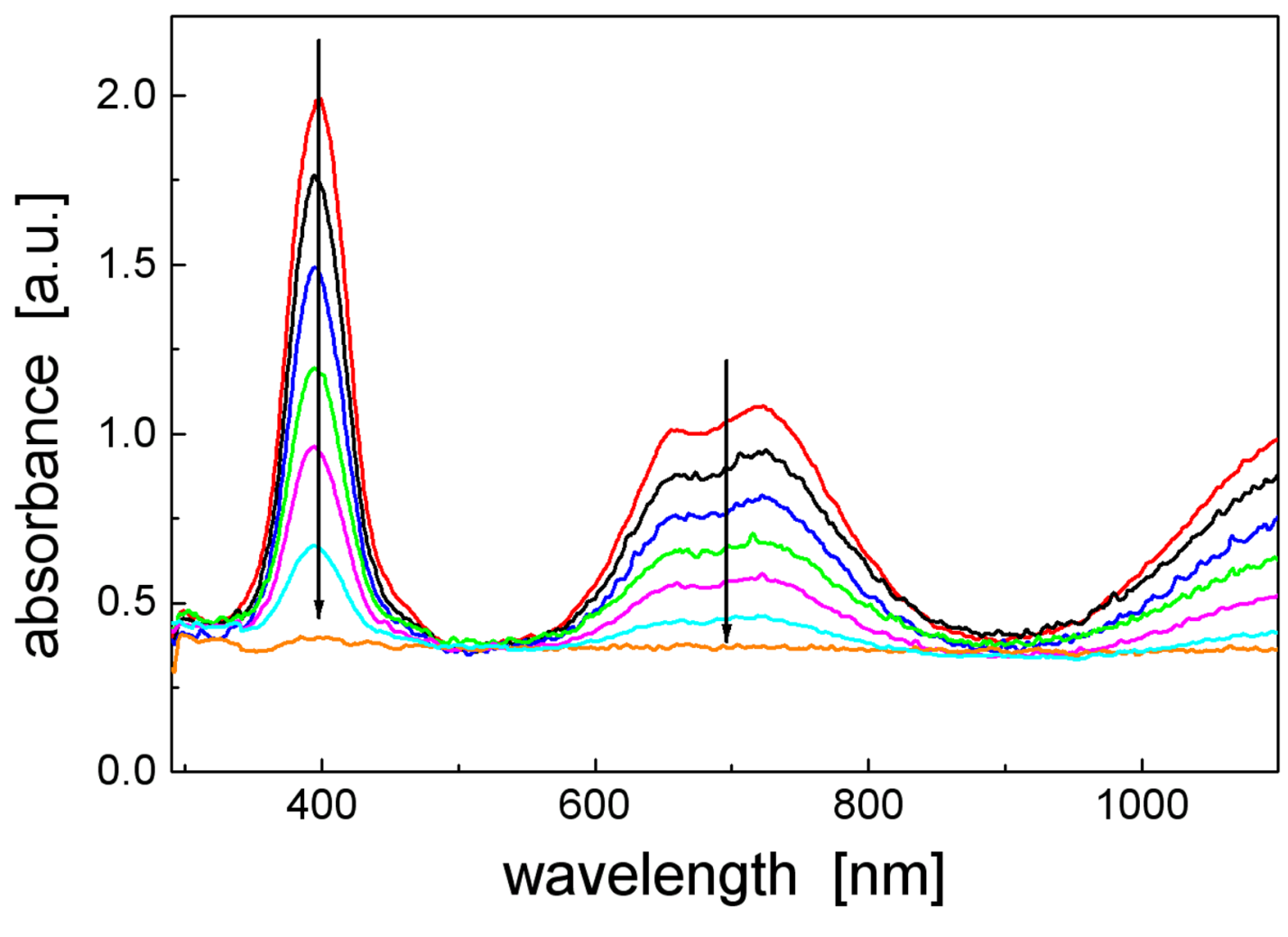

a

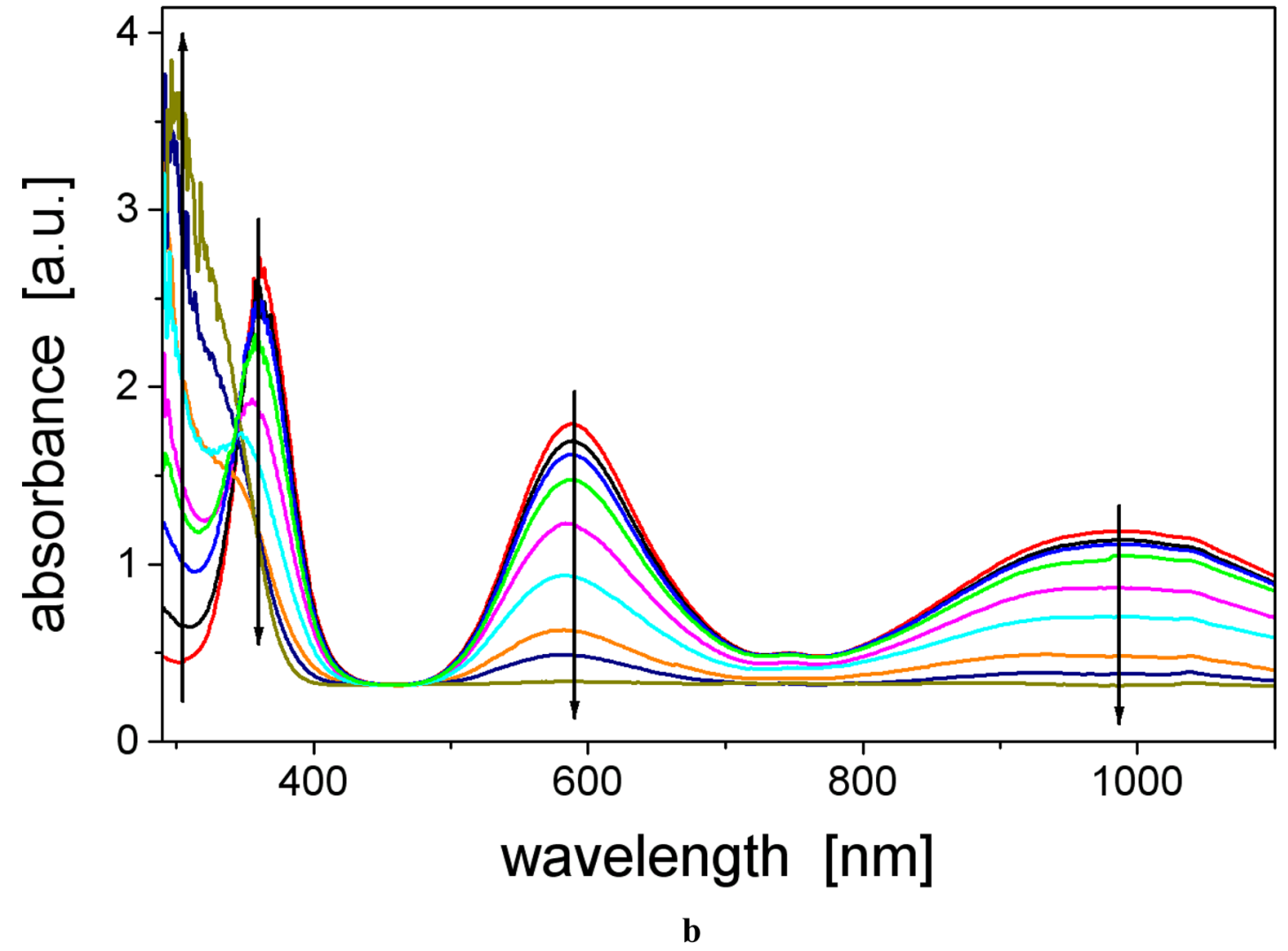


4Fig. 1 UV-Vis spectra recorded during Ni electrodeposition from the acidic (a) and the alkaline (b) bath. Current density of $60 \mathrm{~mA} \mathrm{~cm}{ }^{-2}$; the arrows indicate directions of the spectra changes with time

nickel and $\mathrm{H}_{3} \mathrm{BO}_{3}$ concentrations within the limits quoted above has no influence on the deposition process.

\section{Nickel electrodeposition}

\section{In situ UV-Vis analysis of the plating process}

The electrodeposition was carried out for two types of the baths: the alkaline one (initial $\mathrm{pH}$ of 9.2-9.9) and the acidic one (initial $\mathrm{pH}$ of 4.1-4.5). The plating was performed under controlled current conditions in a two-electrode system which is a set-up frequently used for the Ni targets preparation [2, 5, 16, 18, 20-23, 26, 28, 33]. In situ UVVis measurements with the electrolytic cell placed inside a spectrometer were used to track progress in the plating process. The amount of the electrodeposited nickel equals the amount of the metal removed from the bath. The UV-Vis spectra recorded during the nickel electrodeposition from the alkaline and from the acidic baths are shown in Fig. 1. The spectra reveal shapes typical for aqueous solutions of $\mathrm{NiSO}_{4}$ [60-62]; noises in the curves are produced by gases evolving on the cathode (hydrogen) and on the anode (oxygen). It follows that the time evolution of the spectra depends on the bath $\mathrm{pH}$. Thus, in the acidic bath only, a gradual decrease of Ni peaks at 395 and $659-721 \mathrm{~nm}$ is observed without development of new signals (Fig. 1a). The most intensive Ni(II) peak at $395 \mathrm{~nm}$ was selected to analyse nickel removal from the bath. Evolution of the spectra recorded in the alkaline bath is somewhat more complex because the decrease in the Ni signals at ca. 361 and $583 \mathrm{~nm}$ is accompanied by a simultaneous development of absorption bands below ca. $340 \mathrm{~nm}$ (Fig. 1b). Formation of the latter signals is independent on the $\mathrm{H}_{2} \mathrm{O}_{2}$ presence, and these bands can be attributed to nitrates or other nickel-oxygen compounds [63, 64] which are formed during $\mathrm{NH}_{3}$ oxidation at the platinum anode [65, 66]. These signals eventually overlap the main $\mathrm{Ni}$ peak at ca. $362 \mathrm{~nm}$. Hence, the progress in the Ni electrodeposition from the alkaline bath was analysed using the less intense Ni signal at ca. $588 \mathrm{~nm}$.

It is worth to mention that the system studied was set up in such a way that the spectrophotometer beam was directed into a space between the working and the counter electrodes. This was done in order to reduce the optical path disruption by solid bodies. It follows then that the UV-Vis measurements reflect changes in the nickel cations concentration in the centre of the cuvette which, in turn, may differ from $\mathrm{Ni}^{2+}$ content variation near the electrode surface. Therefore, the results presented in Figs. 1, 2 and 3 provide reliable information about the rate of removal of nickel cations from the bulk of the solution but an analysis of reported UV-Vis data in terms of kinetics of the nickel reduction should be treated with caution since the kinetics is determined by the $\mathrm{Ni}^{2+}$ content next to the electrode surface.

Figure 2 shows rate of removal of $\mathrm{Ni}^{2+}$ ions from the bath due to their reduction and incorporation into the deposited metal layer. The relative fraction of the nickel cations remaining in the bath at time $t$ counted from the start of the deposition, $\mathrm{Ni}_{\text {bath }}$, is calculated using Eq. (1):

$\mathrm{Ni}_{\text {bath }}(t)=\frac{A(t)}{A_{0}} \cdot 100 \%$

where $A_{0}$ and $A(t)$ denote background corrected absorbance before $(t=0)$ and during the deposition at time $t$, respectively. An analysis of the figure shows that the rate of $\mathrm{Ni}$ electrodeposition from the analysed baths strongly depends on $\mathrm{pH}$. Thus, the deposition rate increases with $\mathrm{pH}$, and, for $50-60 \mathrm{~mA} \mathrm{~cm}^{-2}$, the plating of more than $99.5 \%$ of Ni takes ca. $5 \mathrm{~h}$ for $\mathrm{pH}$ of 9.3 (Fig. 2) while for $\mathrm{pH}$ of 4.3 , ca. $95 \%$ of $\mathrm{Ni}$ is deposited within ca. $7.5 \mathrm{~h}$ (Fig. 2). At the end of the deposition process, the $\mathrm{pH}$ of the acidic bath decreases to the level of 1.5-2.3, in a rough agreement with other reports $[19,21]$, while in the alkaline bath, the final $\mathrm{pH}$ reaches the values of 7.1-8.4. It should be stressed, however, that these value were measured after the experiment and they represent $\mathrm{pH}$ averaged for the whole volume of the bath. Thus, conclusions about $\mathrm{pH}$ changes near the electrode surface during the deposition should be drawn with care [59]. In order to simplify the deposition process as much as possible, we did not apply any procedures, such as gradual addition of respective chemicals [37], aimed to maintain the $\mathrm{pH}$ during the electrodeposition.

Complete or almost complete ( $\geq 95 \%)$ deposition of the nickel dissolved in the bath within a reasonable time, such as several hours, requires application of a relatively high current density [33]. This, in turn, leads to a strong polarisation of the cathode which establishes conditions of vigorous hydrogen evolution. This effect significantly reduces faradaic efficiency of the process $[19,26,67]$. The UV-Vis spectra shown in Fig. 2 not only allow tracking progress in the deposition process but also provide data for analysis of faradaic efficiency of the system $(\varepsilon)$. For a given time window $\Delta t=$ $t_{1}-t_{2}$, the latter is expressed by the following Eq. (2):

$\varepsilon\left(t_{2}\right) \frac{\left(\frac{A\left(t_{1}\right)-A\left(t_{2}\right)}{A_{0}}\right) \cdot N_{0} \cdot n \cdot \mathrm{F}}{Q_{\mathrm{m}}} \cdot 100 \%$

where $N_{0}$ is the initial number of moles of nickel present in the bath $(t=0), n$ is the number of electrons exchanged during the $\mathrm{Ni}^{2+}$ reduction $(n=2), \mathrm{F}$ represents the Faraday constant, $Q_{\mathrm{m}}$ stands for measured charge passed in the system 
Fig. 2 Amount of Ni remaining in the electrolyte bath, $\mathrm{Ni}_{\text {bath }}$, calculated from the UV-Vis spectra as a function of the deposition time from an alkaline and an acidic bath. Current density of $60 \mathrm{~mA} \mathrm{~cm}^{-2}$

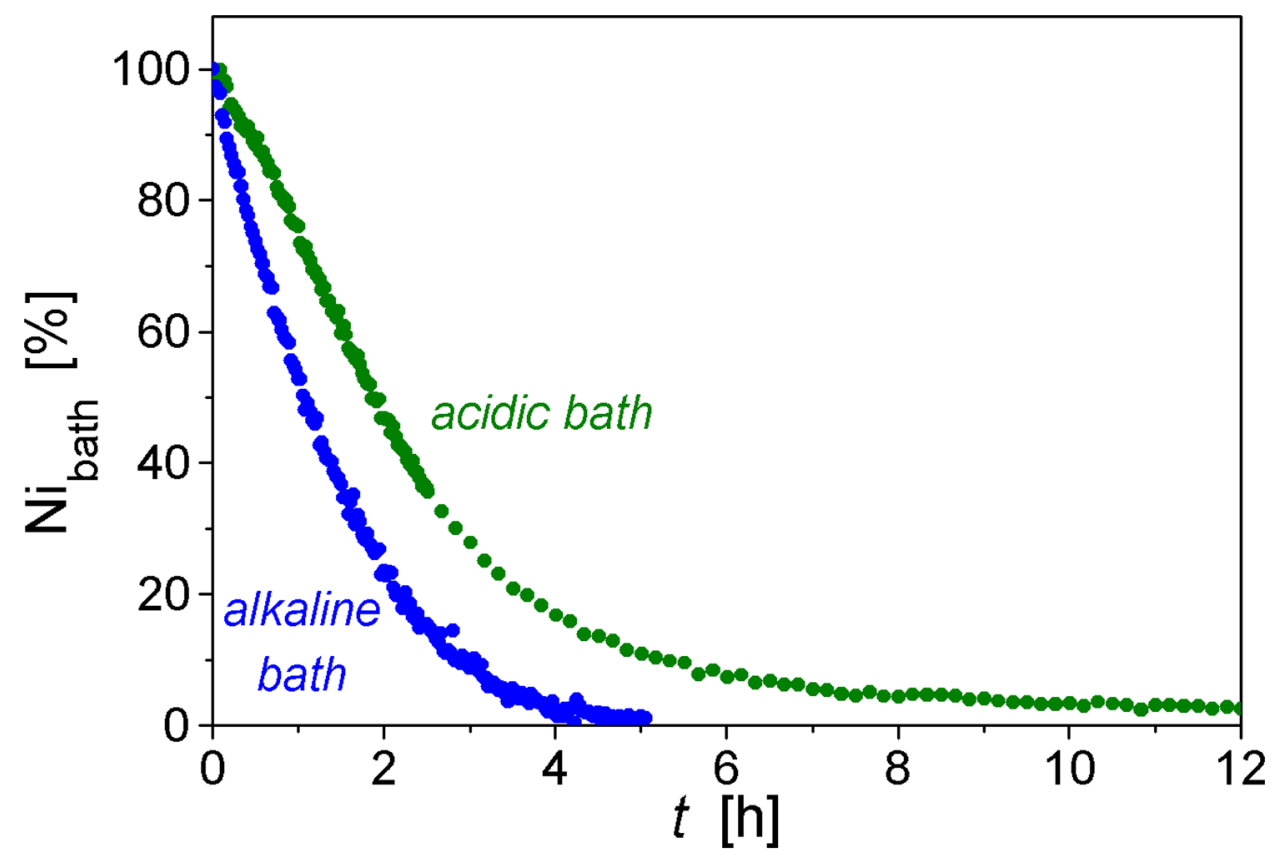

during $\Delta t$ while $A\left(t_{1}\right)$ and $A\left(t_{2}\right)$ indicate absorbance at the beginning and at the end of the time window, respectively. The efficiency is calculated as a temporary value for $\Delta t=100$ $\mathrm{s}$ and $t_{1}$ and $t_{2}$ values continuously growing with the deposition progress. Such calculated values are shown in Fig. 3 as a function of the amount of Ni electrodeposited from the start of the plating process to the time of $t_{2}$. This plot shows temporary efficiency during $100 \mathrm{~s}$ of the plating at the time when the amount of the deposited metal reaches the value given on the abscissa axis. The progress in the nickel deposition was determined on the basis of plots like the ones shown in Fig. 2 (after applying mathematical smoothing procedure). It follows that the faradaic efficiency decreases with the deposition time, and, for the alkaline bath, its maximum value is significantly higher as compared to the acidic electrolyte (ca. $91 \%$ vs. ca. $53 \%$ for deposition of first few per cent of the metal).
Fig. 3 Temporary Faradaic efficiency of the Ni electrodeposition, $\varepsilon$, as a function of the amount of electrodeposited metal. Data for the alkaline (initial $\mathrm{pH}$ of 9.3) and the acidic bath (initial $\mathrm{pH}$ of 4.4), current of $60 \mathrm{~mA} \mathrm{~cm}^{-2}, \Delta t=100 \mathrm{~s}$ (details in the text)

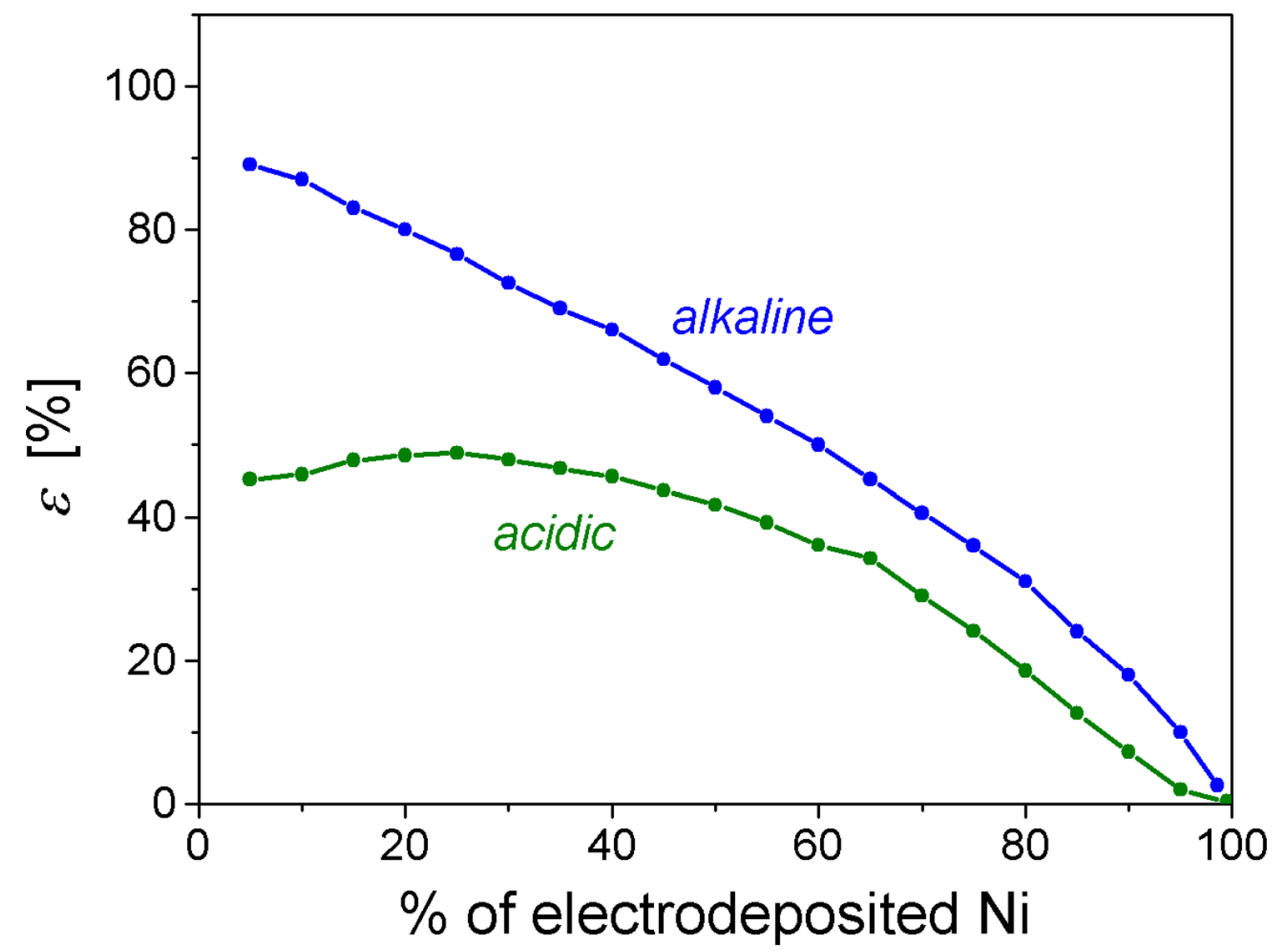




\section{Physical and chemical characterisation of the deposits}

Morphology of the deposit was analysed using scanning electron microscopy. The SEM images shown in Fig. 4 reveal that the quality of the deposit surface is generally better for lower $\mathrm{pH}$ of the bath. The layers deposited from the alkaline bath have a very high surface roughness and contain numerous spherical, cauliflower-like structures and "wells". The latter are typical for the deposition taking place around a high diameter hydrogen bubble attached to the surface [68]. Electrodeposition from the acidic bath, on the other hand, generates significantly smoother surfaces, free of cracks and "wells" and with only a small amount of the spherical features (Fig. 4b). An analysis of SEM images suggests that the deposits obtained from the acidic bath are composed with crystallites of a smaller size as compared to those plated from the alkaline solution.

The deposits plated from the acidic bath are more physically and chemically stable as compared to those plated from the alkaline electrolyte. The latter are brittle and fine fragments of the deposit come off from the substrate easily. Chemical stability of the deposits was evaluated on the basis of a dissolution test. The deposits were placed in concentrated $\mathrm{HNO}_{3}(65 \%)$ at room temperature, and UV-Vis spectra were recorded as a function of the time of the sample immersion in the acid. Figure 5 reveals that the deposit from the alkaline bath dissolves significantly faster than the one deposited from the acidic bath. Eventually, significant fractions of the deposit plated from the alkaline layer peel off from the substrate at the advanced stages of the dissolution process. These fragments fall on the bottom of the cuvette and $\mathrm{Ni}$ cations originating from their dissolution slowly diffuse towards the optical path of the spectrometer. This effect leads to a very slow increase in the $\mathrm{Ni}$ absorbance seen in Fig. 5 at the final stages of the dissolution of the deposit plated from the alkaline bath.

It is likely to assume that the bath composition influence on the morphology of the deposit surface (Fig. 5) is mirrored by different chemical stability of the layers plated from different baths. Thus, the surface roughness of the deposits plated from the alkaline bath is significantly higher as compared to those deposited from the electrolyte with the lower $\mathrm{pH}$ values (Fig. 4). This indicates that the deposits from the alkaline bath possess a higher contact area between dissolving medium and the nickel surface and contain a higher concentration of low coordination number surface atoms prone to easy dissolution as compared to the layers obtained from the acidic electrolyte. Finally, the deposits obtained from the alkaline bath could have a low adhesion to the substrate.

Figures 1, 2, 3, 4 and 5 show that the deposition process strongly depends on the bath composition. It is likely that this effect is caused not only by the $\mathrm{pH}$ variation but is related also to differences in the chemical composition of the acidic and the alkaline bath. Some of the chemicals used for the electrolyte preparation are present only in one type of the bath while chemical forms of those common for both baths may differ due to $\mathrm{pH}$ dependent dissociation. Thus, in the alkaline bath, the $\mathrm{Ni}^{2+}$ exists as an ammonia complex, while in the acidic bath, it forms complexes with water molecules $\left(\mathrm{Ni}^{2+}{ }_{\mathrm{aq}}\right)$, sulphates and/or acetates, depending on the concentration of the complex components [19, 62, 69-72]. A comparison of the spectra recorded in solutions containing sulphates and acetates does not reveal significant differences which point out to similar wavelengths of absorption bands of $\mathrm{Ni}^{2+}$ complexes formed by these two ligands [62, $72,73]$. Further on, it was reported that UV-Vis signals of $\mathrm{Ni}^{2+}$ complexes with acetates overlap $\left(\mathrm{Ni}\left(\mathrm{H}_{2} \mathrm{O}\right)_{6}\right)^{2+}$ bands [72]. Therefore, the identity of $\mathrm{Ni}^{2+}$ complexes present in the bath cannot be unambiguously resolved on the basis of UV-Vis spectra only.

The complexed cations undergo charge transfer reaction leading to formation of $\mathrm{Ni}^{+}$intermediates [57, 69, 74, 75]. The latter are also expected to form complexes with respective agents present in the bath $[57,69,74,75]$. This leads to a conclusion that the electron transfer during reduction of both $\mathrm{Ni}^{2+}$ and $\mathrm{Ni}^{+}$and accompanying processes, such as adsorption of $\mathrm{Ni}$ containing species at the electrode surface, may be strongly affected by the bath composition. The bath chemistry may also influence transport of the electroactive species in the solution since various $\mathrm{Ni}^{2+}$ complexes may differ in respect to their diffusion coefficients [76]. Finally, different species are expected to be adsorbed at the cathode surface depending on the bath composition. This, in turn, may affect morphology of the deposit [77, 78].

The $\mathrm{pH}$ and the bath composition have an impact also on the hydrogen evolution reaction (HER) which takes place simultaneously to the metal deposition. They affect the electrode activity towards HER [79-81] while $\mathrm{pH}$ variation also results in a shift of the reversible potential of $\mathrm{H}^{+} / \mathrm{H}_{2}\left(\mathrm{H}_{2} \mathrm{O} /\right.$ $\mathrm{H}_{2}$ ) red-ox couple in respect to the $\mathrm{Ni} / \mathrm{Ni}^{2+}$ system $[77,82]$. These factors not only may influence the faradaic efficiency but also may have an impact on conditions of $\mathrm{H}_{2}$ bubbles formation. The presence of "wells" seen on SEM image taken for the deposit plated from the alkaline bath (Fig. 4) suggests a strong influence of the $\mathrm{H}_{2}$ bubbles existence on the deposit morphology. The bubble formation depends on the electrode surface properties, which can be modified by the adsorption phenomena, and on the hydrogen solubility in the electrolyte, which depends on the composition of the latter [83-86]. A complex relation between the hydrogen bubbles adhesion to the electrode and morphology (roughness) and wettability of the surface of the latter is reported in the literature [87]. Finally, bubbles of gases released from both the cathode and the anode may affect transport of the electroactive species in the electrolyte (blocking and/or convection) [88]. It follows then that the thorough analysis of 


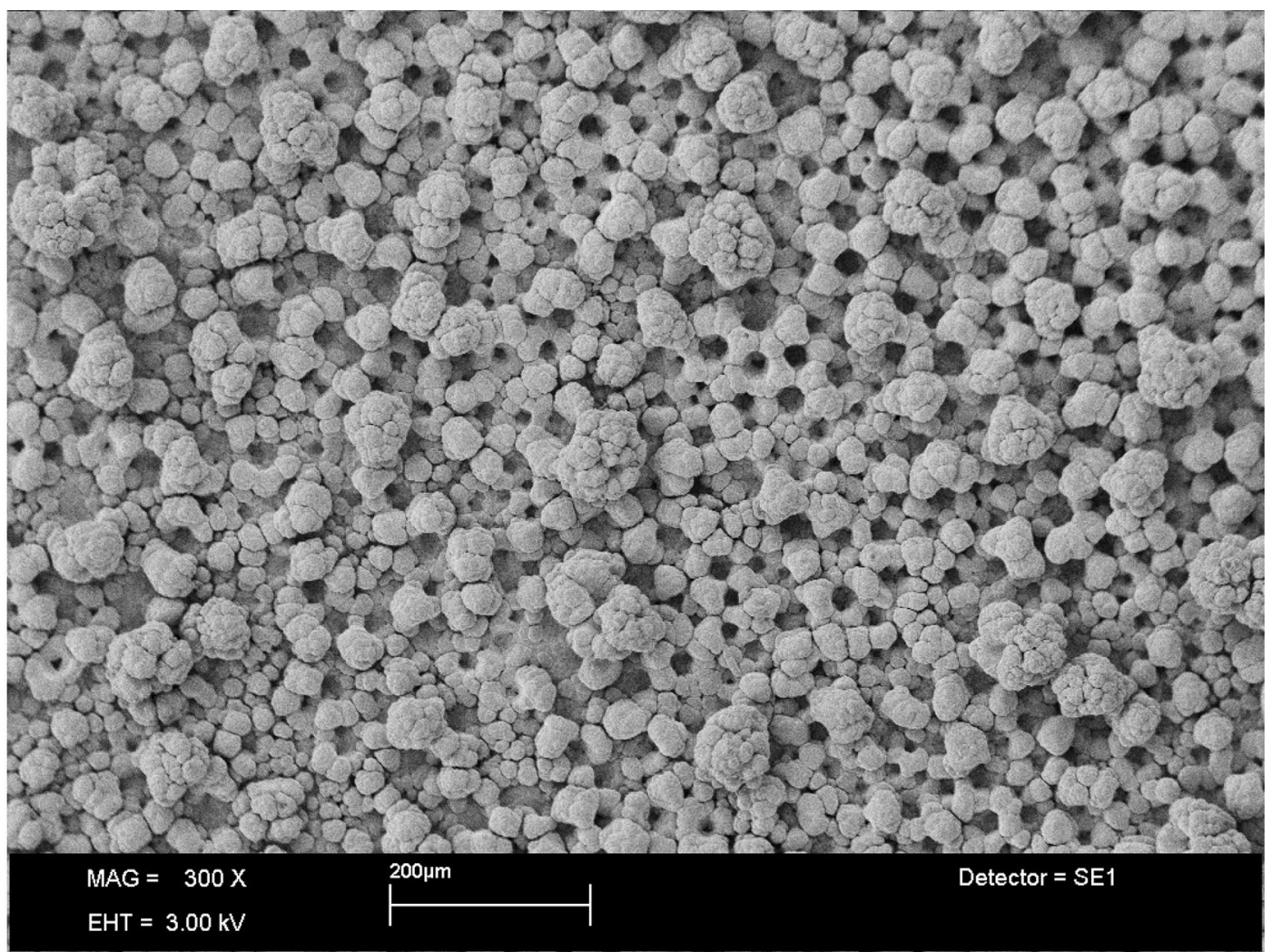

a

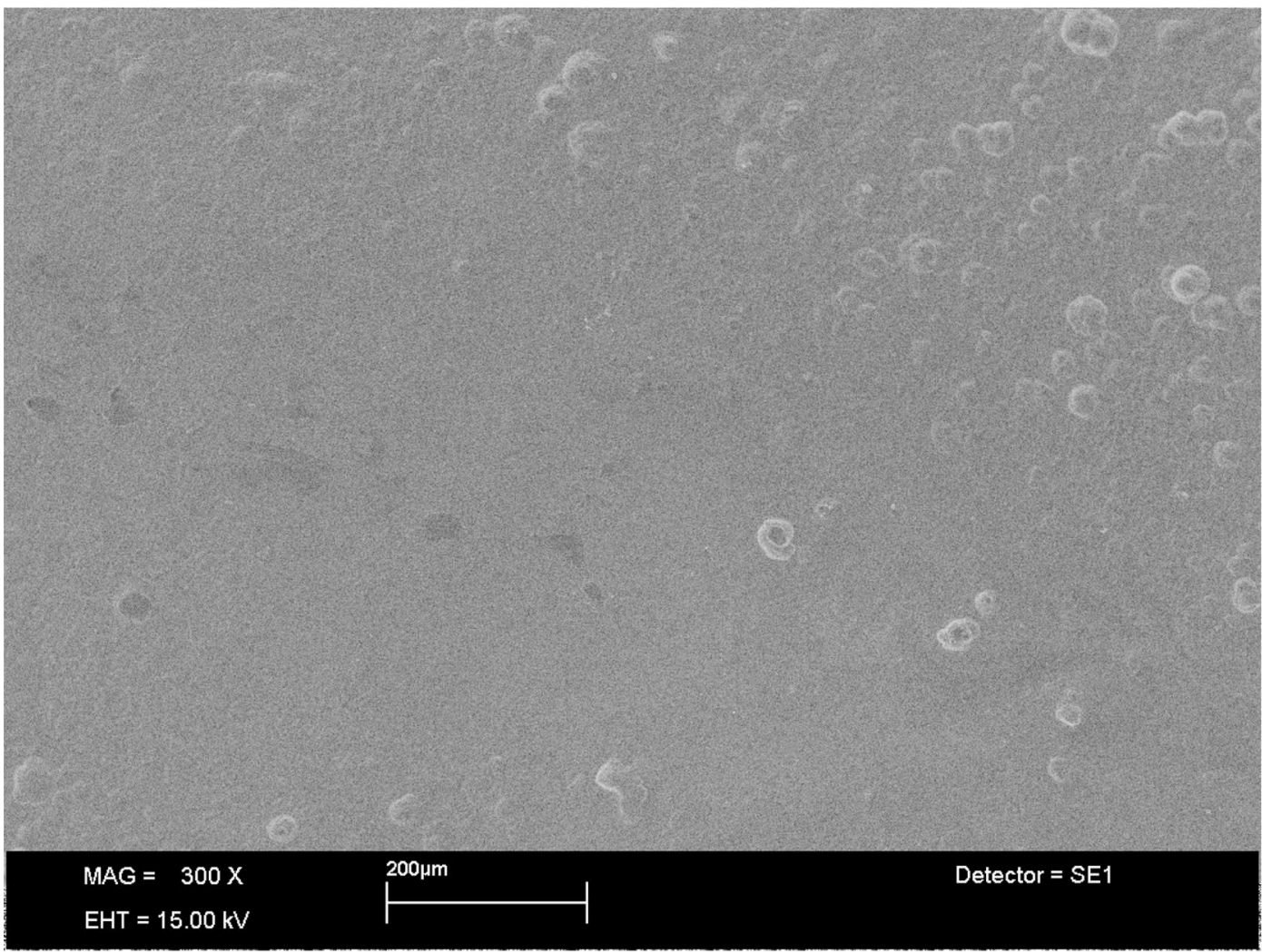

b

Fig. 4 SEM images of the Ni deposits obtained at $60 \mathrm{~mA} \mathrm{~cm}^{-2}$ and from $\mathbf{a}$ alkaline and $\mathbf{b}$ acidic bath. Deposition of more than $98 \%$ of $\mathrm{Ni}$, magnification of $300 \times$ 
Fig. 5 Dissolution of Ni deposits in concentrated $\mathrm{HNO}_{3}$ at room temperature. The deposits were plated from the alkaline and from the acidic baths at current densities of 60 and $50 \mathrm{~mA}$ $\mathrm{cm}^{-2}$, respectively

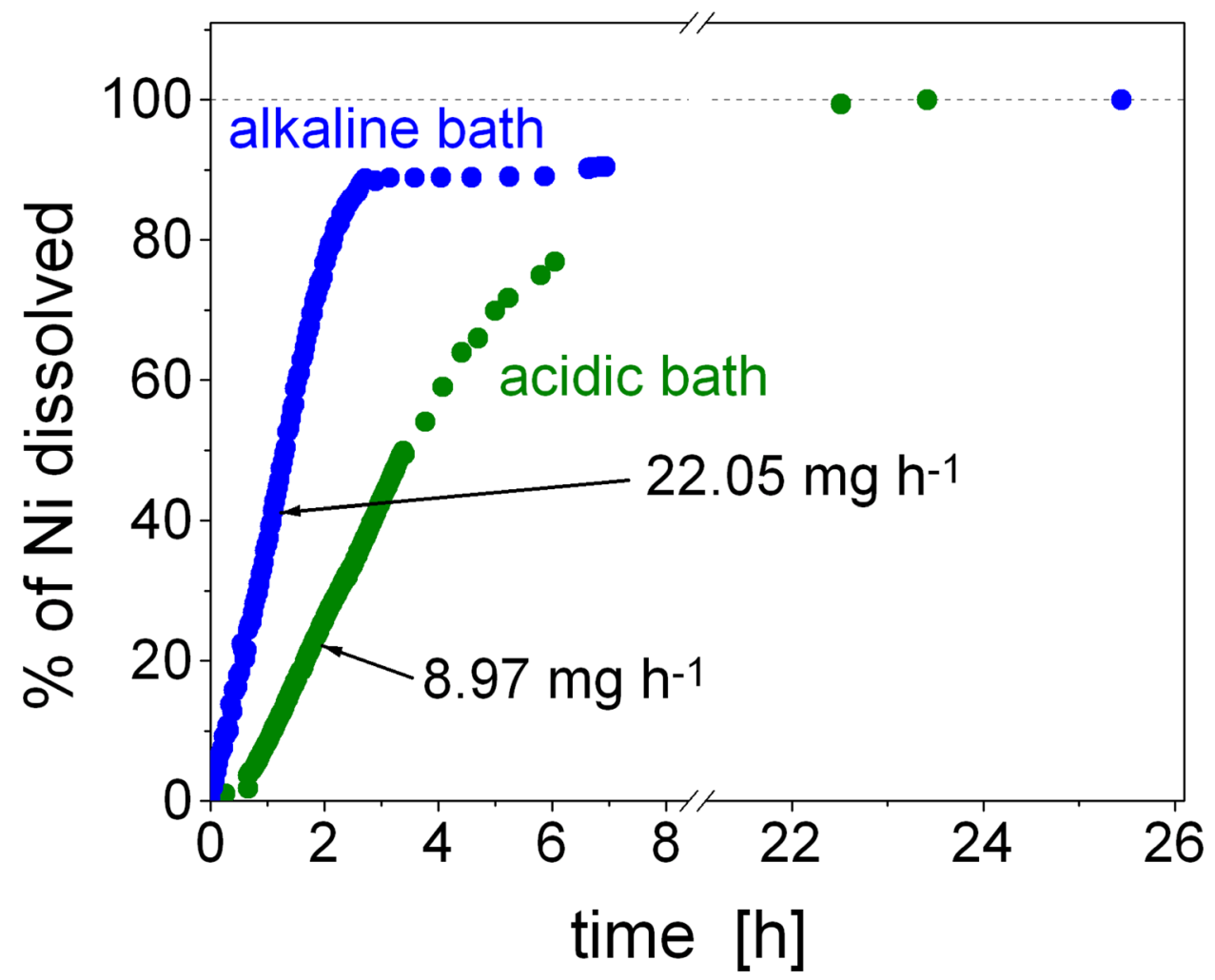

the factors governing the deposit morphology is complex and must consider variation of numerous parameters. At this stage of the studies, as the results are available for two bath compositions only, it is premature to conclude which of the above-mentioned factors is the most important one affecting the deposit morphology.

Figure 6 presents an ED-XRF spectrum recorded for nickel deposited from the acidic and the alkaline baths. It shows that the deposits contain pure nickel. In addition to the above described influence of the bath composition on the deposit properties, it is also worth mentioning that the electrodeposition from the alkaline bath leads to formation of a black deposit on the Pt anode. The same effect is observed also in the absence of $\mathrm{H}_{2} \mathrm{O}_{2}$ when the deposition is carried out from a bath prepared by dissolution of $\mathrm{NiSO}_{4}$ instead of the metallic Ni. The deposit dissolves immediately in concentrated $\mathrm{HNO}_{3}$, and, as a separate ED-XRF analysis reveals, it contains nickel (Fig. 7). The most likely explanation is formation of NiOOH in an anodic reaction proposed in [89]. An analysis shows that concentration of $\mathrm{Ni}$ ions originating from dissolution of this anodic deposit is below UV-Vis detection limit (the same analysis conditions as for the electrodeposition process). It follows then that the amount of $\mathrm{Ni}$ deposited on the anode constitutes a meaningless fraction of the overall mass of the metal dissolved in the bath.

\section{Estimation of $\mathrm{H}_{2} \mathrm{O}_{2}$ content in the electrolyte bath}

The presence of the hydrogen peroxide in the galvanic bath may affect nickel deposition process. Thus, $\mathrm{H}_{2} \mathrm{O}_{2}$ can be electrochemically reduced using solid electrodes, such as Ni $[90,91]$. When this reaction takes place parallel to the metal plating, it may reduce the Faradaic efficiency of the electrodeposition process [43]. On the other hand, it was reported that the presence of some amounts of $\mathrm{H}_{2} \mathrm{O}_{2}$ in the nickel plating bath can be beneficial for elimination of pits in the deposit [92] and may reduce hydrogen uptake by the deposit [67]. As regards the anodic processes, Ni dissolution prevails over passivation in the presence of the peroxide in the electrolyte [93]. This may take place when the Ni electrode is accidentally left in the bath under open circuit conditions. It is then interesting to determine the amount of the $\mathrm{H}_{2} \mathrm{O}_{2}$ remaining in the bath after completing the nickel dissolution. Hydrogen peroxide can be catalytically decomposed by $\mathrm{Ni}^{2+}$ cations [94-97], and the rate of this reaction increases when $\mathrm{pH}$ is changed from the acidic to the alkaline one [95]. Because of this reason, as well as due to more promising results of the plating from the acidic bath, we focus our analysis on determination of $\mathrm{H}_{2} \mathrm{O}_{2}$ in the latter electrolyte only.

The method applied by us is based on detection of Fe(III) species generated by $\mathrm{Fe}(\mathrm{II})$ oxidation with the hydrogen peroxide [98-101]. The detailed scheme of the reactions 


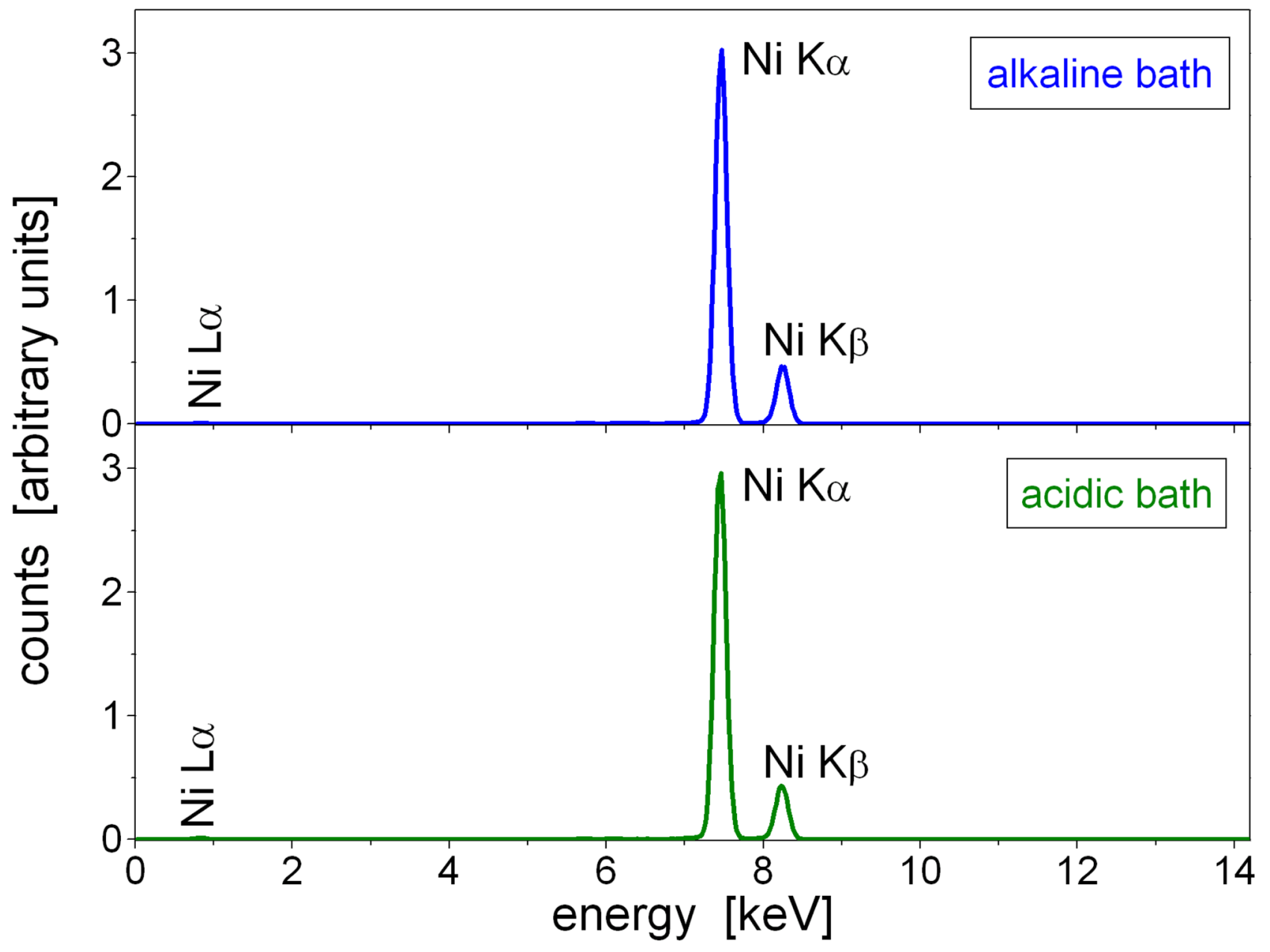

Fig. 6 ED-XRF spectrum of $\mathrm{Ni}$ deposited from the alkaline (initial $\mathrm{pH}=9.3$, top panel) and from the acidic bath (initial $\mathrm{pH}=4.3$, bottom panel). Current density of $60 \mathrm{~mA} \mathrm{~cm}^{-2}$

taking place in this process is complex [102-104], especially in the presence of the acetates which may react with generated radicals [105], and its discussion is out of scope of this paper. Due to a complex composition of the bath, we did not add any $\mathrm{Fe}$ (III) complexing agents which may improve attenuation coefficient of iron containing species. Test solutions free of $\mathrm{H}_{2} \mathrm{O}_{2}$ were prepared by dissolving $\mathrm{NiSO}_{4}$ instead of the Ni powder. The amount of $\mathrm{H}_{2} \mathrm{SO}_{4}$, $\mathrm{H}_{3} \mathrm{BO}_{3}$ and $\mathrm{CH}_{3} \mathrm{COONa}$ added to the test solutions as were as $\mathrm{Ni}^{2+}$ concentration in the latter were the same as for the acidic electrolyte bath. Such obtained solution was diluted to $6 \mathrm{ml}$. In the next step, $0.403 \pm 0.006 \mathrm{~g}$ of $\mathrm{FeSO}_{4} \cdot 7 \mathrm{H}_{2} \mathrm{O}$ was added. $\mathrm{Fe}$ (II) was in a molar excess in respect to the maximum possible concentration of $\mathrm{H}_{2} \mathrm{O}_{2}(0.39-0.93 \mathrm{M}$ in respect to the undiluted bath). Further on, addition of such high amount of iron improves ratio of iron to nickel signals in the spectrum. This makes iron signals less affected by the nickel absorption bands. Hydrous $\mathrm{FeSO}_{4}$ dissolves relatively quickly in the test solution and such prepared mixture remains stable over a long period of time. This is in contrast to other methods of $\mathrm{H}_{2} \mathrm{O}_{2}$ determination, such as the one based on a reaction with $\mathrm{KMnO}_{4}[106,107]$. We found that the addition of the permanganates to the test solutions leads to immediate precipitation of a deposit even in the absence of the hydrogen peroxide. Therefore, we do not investigate further this approach.

Various amounts of $\mathrm{H}_{2} \mathrm{O}_{2}$ were added to the test solutions, and respective UV-Vis spectra show how the amount of $\mathrm{Fe}(\mathrm{III})$ and $\mathrm{Fe}(\mathrm{II})$ varies as a function of the peroxide concentration (Fig. 8). The solutions remain stable for at least several tens of minutes after adding a single portion of $\mathrm{H}_{2} \mathrm{O}_{2}$, as follows from the spectra analysis. The spectra reveal out of scale signals due to $\mathrm{Fe}(\mathrm{II})$ and $\mathrm{Fe}$ (III) below ca. $482 \mathrm{~nm}[108,109]$, strongly overlapping signals at ca. 448 and ca. $510 \mathrm{~nm}$ and a wide peak at 970-1005 nm. Nickel signals at $659-721 \mathrm{~nm}$ are poorly visible due to dilution of the bath while the peak at ca. $395 \mathrm{~nm}$ overlap $\mathrm{Fe}$ signals located in this wavelength range, including the 
Fig. 7 ED-XRF spectrum of $\mathrm{Pt}$ anode after completing $\mathrm{Ni}$ deposition from the alkaline bath (initial $\mathrm{pH}$ of 9.3) with the current of $60 \mathrm{~mA} \mathrm{~cm}^{-2}$

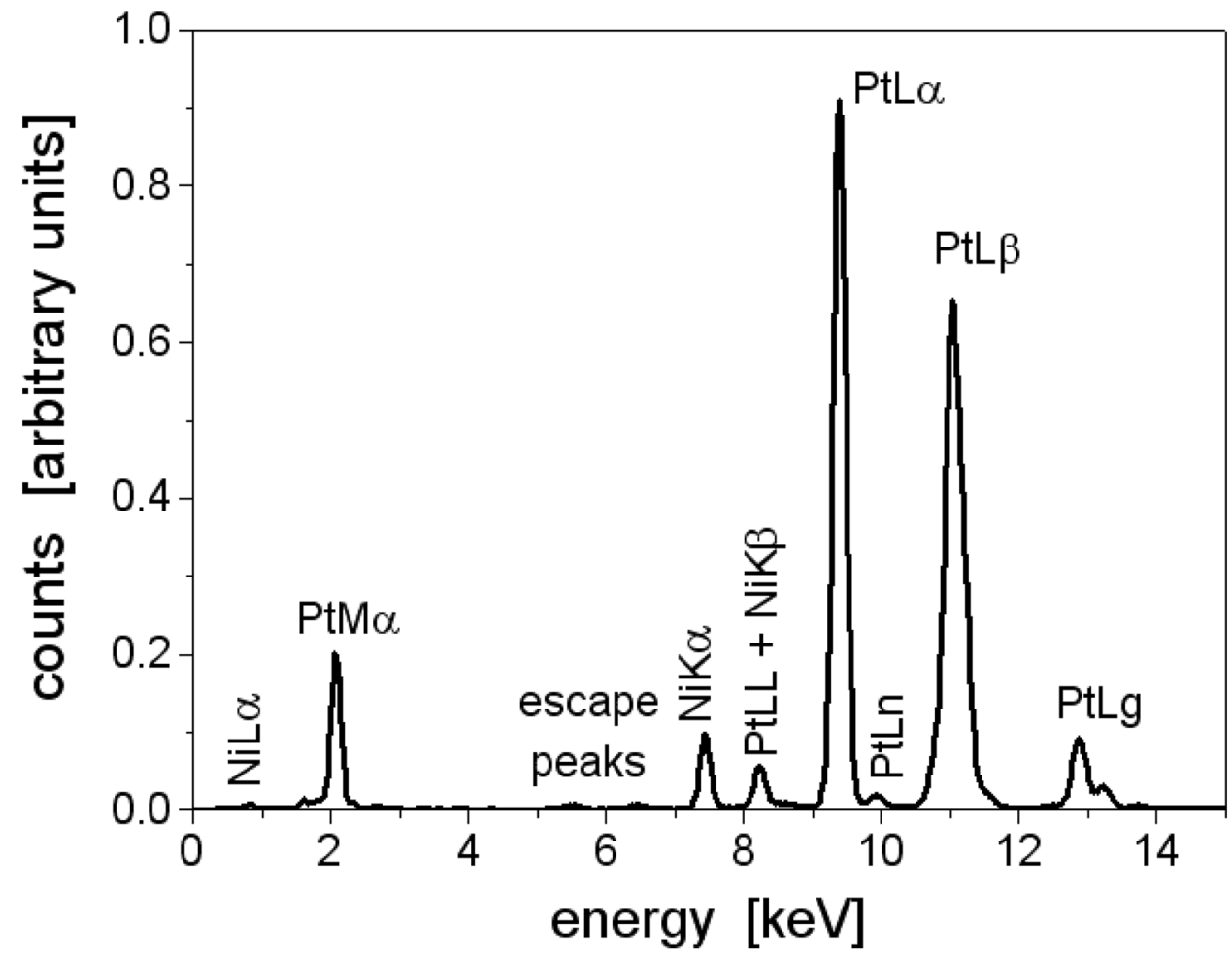

ones attributed to acetate complexes of Fe(III) and located below ca. $480 \mathrm{~nm}[110,111]$. Signals at ca. $510 \mathrm{~nm}$ and ca. 970-1005 $\mathrm{nm}$ are assigned to acetate complexes of $\mathrm{Fe}(\mathrm{III})$ [111-113]. Their intensity increases with the $\mathrm{H}_{2} \mathrm{O}_{2}$ content due to generation of $\mathrm{Fe}(\mathrm{III})$ in a reaction with the latter. The maximum of the peak at 1005-970 nm shifts towards lower wavelengths with the addition of $\mathrm{H}_{2} \mathrm{O}_{2}$, i.e. with the increasing concentration of generated Fe(III). This
Fig. 8 UV-Vis spectra of tests solutions containing $0.403 \mathrm{~g}$ of $\mathrm{FeSO}_{4} \cdot 7 \mathrm{H}_{2} \mathrm{O}$ and various amounts of $\mathrm{H}_{2} \mathrm{O}_{2}$ added (from $7.8 \cdot 10^{-5}$ to $4.7 \cdot 10^{-4} \mathrm{M}$ per 6 $\mathrm{ml}$ of the solution). The arrows indicate evolution of the spectra with increasing amount of added $\mathrm{H}_{2} \mathrm{O}_{2}$; horizontal dotted line indicates location of the signal at $510 \mathrm{~nm}$. A spectrum recorded for diluted acidic bath containing $0.403 \mathrm{~g}$ of $\mathrm{FeSO}_{4} \cdot 7 \mathrm{H}_{2} \mathrm{O}$ is also shown

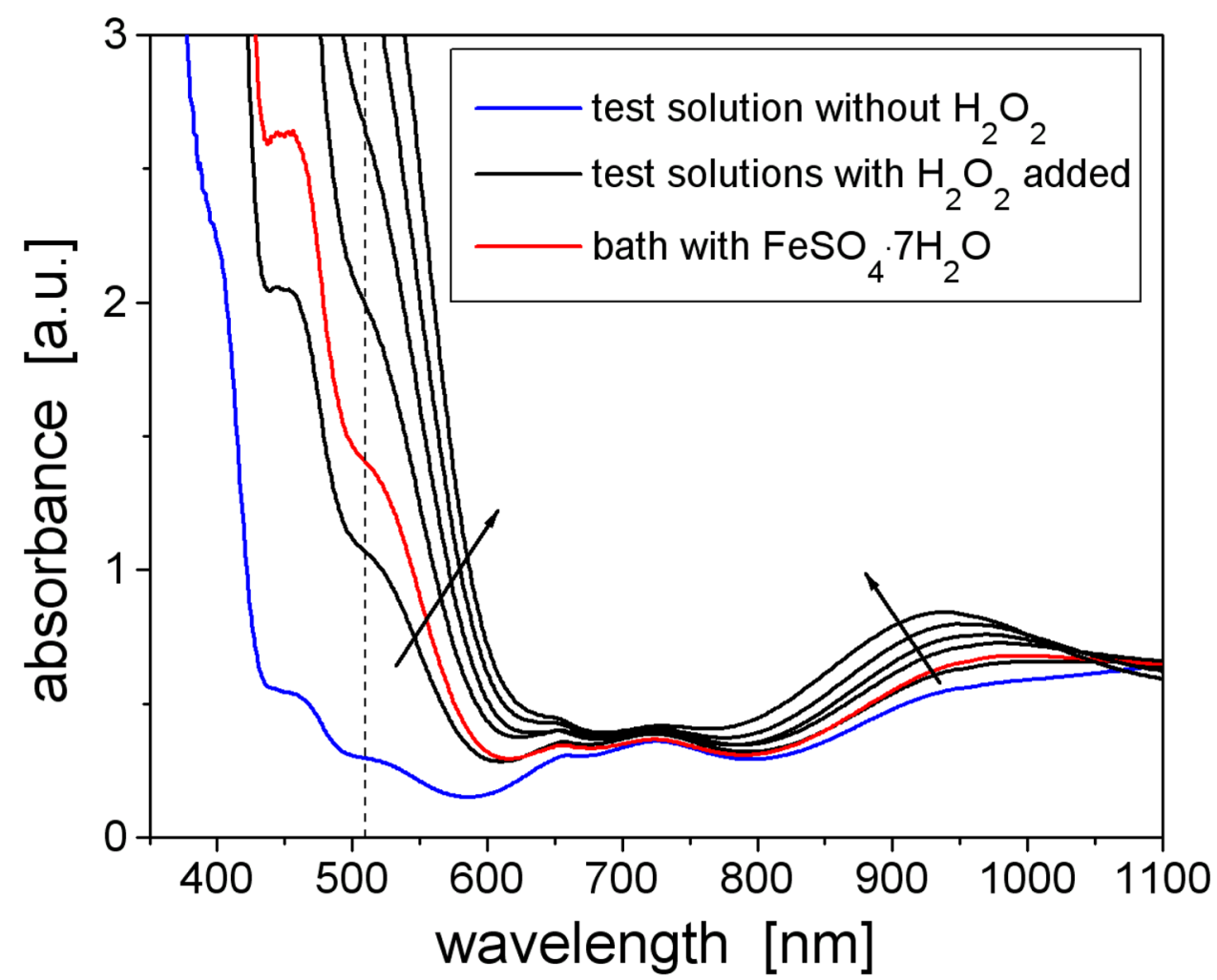


effect can be attributed to variation in stoichiometry of the $\mathrm{Fe}$ (III)-acetate complexes due to changes in the $\mathrm{Fe}$ (III) concentration. For a sufficiently high amount of $\mathrm{H}_{2} \mathrm{O}_{2}$ added the signal at $510 \mathrm{~nm}$ eventually overlaps other bands which onset shifts to higher wavelength as the amount the peroxide added increases. Thus, due to a complex composition of the bath, as well as complicated shape of the UV-Vis spectra, we apply an analysis aimed to a rough estimation of the peroxide content and we do not made attempts to determine it with high accuracy. We found that only analysis of signals at $510 \mathrm{~nm}$ (corrected for baseline value at 610-630 nm) and ca. 970-1005 nm (corrected for arbitrarily selected baseline value at $1100 \mathrm{~nm}$ ) delivers reasonable results. Respective calibration curves constructed on the basis of UV-Vis spectra recorded for the test solutions are shown in Fig. 9. Regardless on relatively high scatter of the experimental data points, the plots reveal a reasonably good linearity.

The spectra recorded for the test solutions were compared with the electrolyte bath prepared by dissolution of $50-53 \mathrm{~g}$ of $\mathrm{Ni}$ in a mixture containing $0.1 \mathrm{ml} \mathrm{H}_{2} \mathrm{O}_{2}$ and $0.5 \mathrm{ml} 3 \mathrm{M} \mathrm{H}_{2} \mathrm{SO}_{4}$. The solution was then diluted with water to the volume of $2.1 \mathrm{ml}$. The added chemicals include $\mathrm{CH}_{3} \mathrm{COONa}$ (setting up pH of 4.3-4.4) and $\mathrm{H}_{3} \mathrm{BO}_{3}$ (final concentration of $0.32 \mathrm{M}$ ). This was the standard composition of the acidic bath used in the experiments described in the previous chapters. Such prepared bath was subjected to dilution to $6 \mathrm{ml}$ and $0.403 \pm 0.006 \mathrm{~g}$ of $\mathrm{FeSO}_{4} \cdot 7 \mathrm{H}_{2} \mathrm{O}$ was added (red curve in Fig. 8). The bath treatment was simplified as much as possible in order to avoid accidental $\mathrm{H}_{2} \mathrm{O}_{2}$ decomposition. Therefore, the electrolyte was subjected only to a slight dilution which does not affect $\mathrm{pH}$ significantly. A comparison of the results of analysis of the signal at $510 \mathrm{~nm}$ and the band at ca. 970-1005 nm shows that the amount of the peroxide determined using these two approaches differs by less than $15 \%$. Thus, the reported below values are the averages of the results obtained for both these signals. The analysis shows that the estimated $\mathrm{H}_{2} \mathrm{O}_{2}$ concentration in the bath varies from 0.057 to $0.070 \mathrm{M}$ for 53 and $50 \mathrm{mg}$ of dissolved $\mathrm{Ni}$, respectively (concentrations given in respect to the undiluted bath). Although $\mathrm{H}_{2} \mathrm{O}_{2}$ can be consumed in a reaction with the acetates, this process is rather slow in the absence of respective catalysts [114]. This, in connection with the fact that the peroxide is detected in the electrolytic bath, suggests that possible decomposition of $\mathrm{H}_{2} \mathrm{O}_{2}$ via processes different than the nickel oxidation/ dissolution is of a minor importance. Thus, ca. 8.6 $10^{-4}$ and ca. $8.3 \cdot 10^{-4}$ moles underwent the reaction with 53 and $50 \mathrm{mg}$ of the metallic nickel powder, respectively. It follows then that the molar ratio of consumed $\mathrm{H}_{2} \mathrm{O}_{2}$ to $\mathrm{Ni}$ is equal to 0.95 . Taking into account that the reaction of
$\mathrm{H}_{2} \mathrm{O}_{2}$ with $\mathrm{Ni}(0)$ may proceed according two pathways with stoichiometries equal to $1: 1$ (formation of $\mathrm{Ni}(\mathrm{II})$ ) or 3:2 (formation of $\mathrm{Ni}(\mathrm{III})$ ) [115], one may conclude that most of the metal is dissolved in a reaction with the peroxide while dissolution through a direct reaction with $\mathrm{H}_{2} \mathrm{SO}_{4}[116,117]$ plays a minor role. Nickel is slowly dissolved in acids, including $\mathrm{H}_{2} \mathrm{SO}_{4}[116,118]$, but this process can be facilitated by presence of atmospheric oxygen dissolved in the solution [117].

Knowing the amount of $\mathrm{H}_{2} \mathrm{O}_{2}$ present in the bath, one may estimate influence of the charge of the possible peroxide reduction on the overall faradaic efficiency of the process. It is assumed here that the electroreduction of $\mathrm{H}_{2} \mathrm{O}_{2}$ is a two electron process [90, 119-122]). A comparison of the charge required for the complete deposition of $\mathrm{Ni}$ with the one needed for reduction of the peroxide remaining in the bath shows that the latter should not exceed $16 \%$ of the former. It is also important to note that $\mathrm{H}_{2} \mathrm{O}_{2}$ reduction can be significantly retarded at potentials where the electrode surface becomes covered with adsorbed hydrogen [121]. This point, however, cannot be further evaluated because coverage of Ni electrode surface with adsorbed hydrogen at potentials of HER is a matter of debate [123]. Clearly, the peroxide reduction is only slightly responsible for the low Faradaic efficiency depicted in Fig. 3. It is worth to note that $\mathrm{H}_{2} \mathrm{O}_{2}$ is expected to be decomposed also via catalytic oxidation on the platinum anode surface [119, 121, 124]. This reduces the amount of the peroxide which interacts chemically and electrochemically with the cathode and, consequently, diminishes the $\mathrm{H}_{2} \mathrm{O}_{2}$ influence on the deposition process. Thus, the main factors responsible for differences between the faradaic efficiency calculated for the acidic and the alkaline baths are those related to the $\mathrm{pH}$ and the bath composition influence on the nickel electrodeposition and on the hydrogen evolution reaction (reversible potential and kinetic parameters). More data are required to conclude which of these two factors governs the faradaic efficiency.

An attempt was made to neutralise $\mathrm{H}_{2} \mathrm{O}_{2}$ in the acidic bath using its reduction with sulphites [107, 125, 126]. $\mathrm{Na}_{2} \mathrm{SO}_{3}$ was added in a twofold excess over the $\mathrm{H}_{2} \mathrm{O}_{2}$ concentration. Deposits obtained from this bath are of very poor quality, i.e. brittle, with very rough surface and, as follows from an ED-XRF analysis (not shown), they contain significant amounts of sulphur. Therefore, this approach was no longer considered. Another possibility of the peroxide removal is a catalytic decomposition using metallic Pt [44, 127]. Indeed, such reaction is observed in the system after immersing massive platinum, e.g. wire. However, we did not make further attempts to remove $\mathrm{H}_{2} \mathrm{O}_{2}$ because quality of the deposits obtained from the acidic baths in the presence of the peroxide was found to be acceptable. 


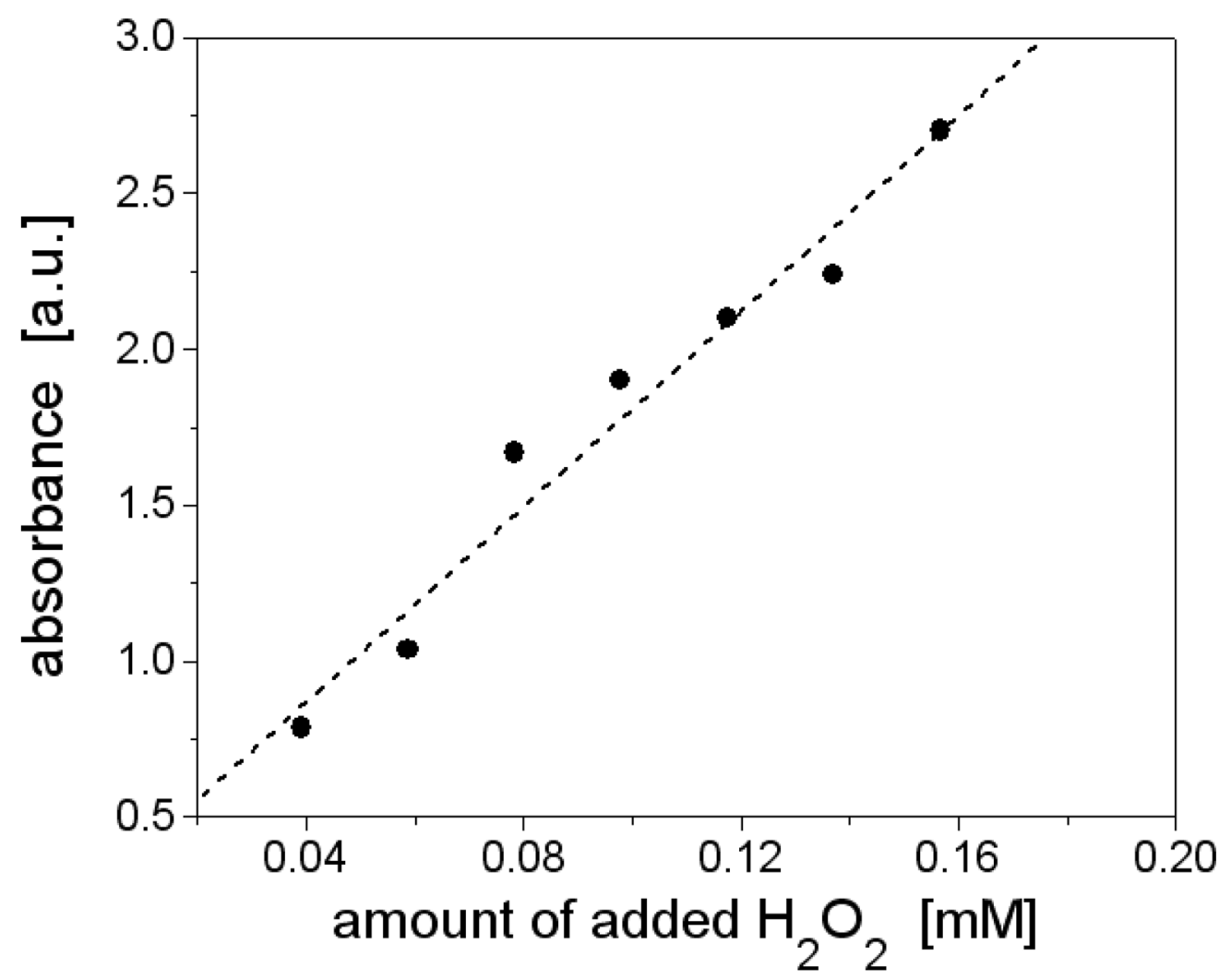

a

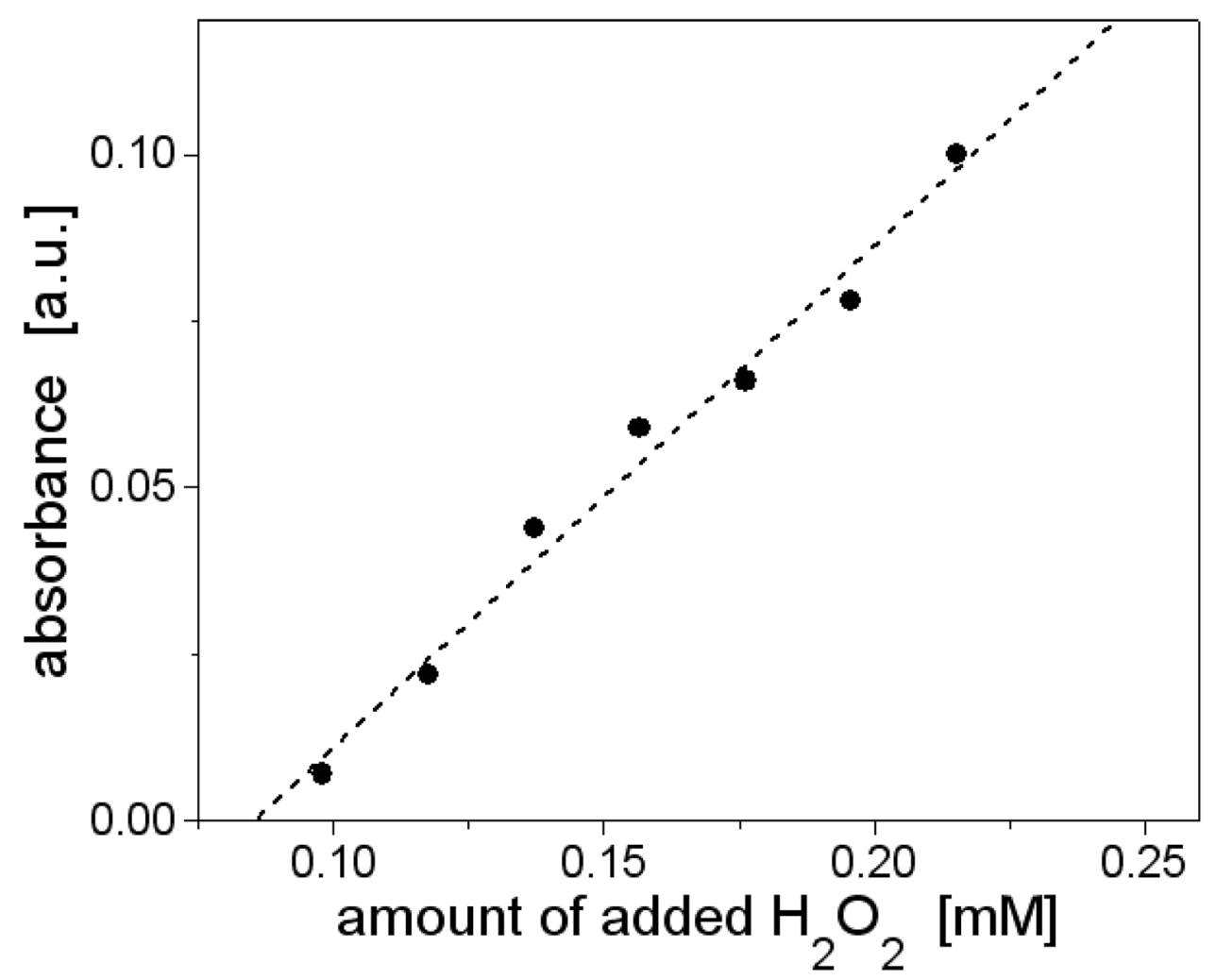

b

Fig. 9 UV-Vis spectroscopy calibration curves constructed on the basis of spectra recorded for test solutions. a Signal at $510 \mathrm{~nm}$; b signal at $970-1005 \mathrm{~nm}$ 


\section{Conclusions}

This paper deals with a new method of preparation of the electrolyte baths for nickel electrodeposition with metallic Ni powder used as a starting material. The powder can be quickly dissolved in a $\mathrm{HNO}_{3}$-free solution. Such obtained mixture can be used for preparation of nitrates-free plating baths without additional procedures aimed to remove the nitrates. Neutralisation of the solution with $\mathrm{NH}_{4} \mathrm{OH}$ or acetates allows obtaining electrolyte baths with $\mathrm{pH}$ ranging from the alkaline to the acidic one. Electrodeposition of more than $99 \%$ of ca. $50 \mathrm{mg}$ of $\mathrm{Ni}$ dissolved in the bath takes ca. $5 \mathrm{~h}$ for the alkaline electrolyte while for the acidic solution, ca. $95 \%$ of the metal is deposited within ca. 7 h. The deposits obtained from the acidic baths are more physically and chemically stable than those deposited from the alkaline solution. The surface of the former is crackfree and is smoother as compared to the deposits obtained at higher $\mathrm{pH}$. The described method can be applied for preparation of $\mathrm{Ni}$ targets used for accelerator production of radioisotopes for medical applications. The amount of $\mathrm{H}_{2} \mathrm{O}_{2}$ remaining in the bath can be roughly estimated using a reaction of $\mathrm{Fe}(\mathrm{II})$ oxidation and by determination of such formed $\mathrm{Fe}$ (III) by means of UV-Vis spectroscopy.

Funding Financial support from Faculty of Chemistry, University of Warsaw (grant nos. 501-D112-01-1120000 (501100299, 5011000357) and 501-D112-64-0185200-80) was received. The contribution of Martyna Próchniak (née Mieszkowska), M.Sc., was realized within Project No. POWR.03.02.00-00-I009/17-00 (Operational Project Knowledge Education Development 2014-2020 co-financed by European Social Fund).

Open Access This article is licensed under a Creative Commons Attribution 4.0 International License, which permits use, sharing, adaptation, distribution and reproduction in any medium or format, as long as you give appropriate credit to the original author(s) and the source, provide a link to the Creative Commons licence, and indicate if changes were made. The images or other third party material in this article are included in the article's Creative Commons licence, unless indicated otherwise in a credit line to the material. If material is not included in the article's Creative Commons licence and your intended use is not permitted by statutory regulation or exceeds the permitted use, you will need to obtain permission directly from the copyright holder. To view a copy of this licence, visit http://creativecommons.org/licenses/by/4.0/.

\section{References}

1. Smith SV, Jones M, Holmes V (2011) Production and selection of metal PET radioisotopes for molecular imaging. In: $\mathrm{N}$ Singh (ed) Radioisotopes - applications in bio-medical science. InTech, Rijeka

2. Avila-Rodriguez MA, Nye JA, Nickles RJ (2007) Simultaneous production of high specific activity ${ }^{64} \mathrm{Cu}$ and ${ }^{61} \mathrm{Co}$ with
11.4MeV protons on enriched ${ }^{64} \mathrm{Ni}$ nuclei. Appl Radiat Isot 65:1115-1120

3. Ahmedova A, Todorov B, Burdzhiev N, Goze C (2018) Copper radiopharmaceuticals for theranostic applications. Eur J Med Chem 157:1406-1425

4. Qaim SM (2019) Theranostic radionuclides: recent advances in production methodologies. J Radioanal Nucl Chem 322:1257-1266

5. Spellerberg S, Reimer P, Blessing G, Coenen HH, Qaim SM (1998) Production of ${ }^{55} \mathrm{Co}$ and ${ }^{57} \mathrm{Co}$ via proton induced reactions on highly enriched ${ }^{58} \mathrm{Ni}$. Appl Radiat Isot 49:1519-1522

6. Tárkány F, Szelecsenyi F, Kopecky P (1991) Excitation functions of proton induced nuclear reactions on natural nickel for monitoring beam energy and intensity. Appl Radiat Isot 42:513-517

7. Valdovinos HF, Hernandez R, Graves S, Ellison PA, Barnhart TE, Theuer CP, Engle JW, Cai W, Nickles RJ (2017) Cyclotron production and radiochemical separation of ${ }^{55} \mathrm{Co}$ and ${ }^{58 \mathrm{~m}} \mathrm{Co}$ from ${ }^{54} \mathrm{Fe},{ }^{58} \mathrm{Ni}$ and ${ }^{57} \mathrm{Fe}$ targets. Appl Radiat Isot 130:90-101

8. Boros E, Packard AB (2019) Radioactive transition metals for imaging and therapy. Chem Rev 119:870-901

9. Vallabhajosula S (2009) Molecular imaging: radiopharmaceuticals for PET and SPECT. Springer, Heidelberg

10. Jalilian AR, Osso J Jr (2017) The current status and future of theranostic Copper-64 Radiopharmaceuticals. Iran J Nucl Med 25:1-10

11. Bailey DL, Townsend DW, Valk PE, Maisey MN (2005) Positron emission tomography. Basic Sciences. Springer, London

12. Ikotun OF, Lapi SE (2011) The rise of metal radionuclides in medical imaging: copper-64, zirconium-89 and yttrium- 86 . Future Med Chem 3:599-621

13. Qaim SM, Spahn I (2018) Development of novel radionuclides for medical applications. J Label Comp Radiopharm 61:126-140

14. Szymański P, Frączek T, Markowicz M, Mikiciuk-Olasik E (2012) Development of copper based drugs, radiopharmaceuticals and medical materials. Biometals 25:1089-1112

15. Fiedler L, Kellner M, Oos R, Böning G, Ziegler S, Bartenstein P, Zeidler R, Gildehaus FJ, Lindner S (2018) Fully automated production and characterization of ${ }^{64} \mathrm{Cu}$ and proof-of-principle small-animal PET imaging using ${ }^{64} \mathrm{Cu}$-labelled CA XII targeting 6A10 Fab. ChemMedChem 13:1230-1237

16. McCarthy DW, Shefer RE, Klinkowstein RE, Bass LA, Margeneau WH, Cutler CS, Anderson CJ, Welch MJ (1997) Efficient production of high specific activity ${ }^{64} \mathrm{Cu}$ using a biomedical cyclotron. Nucl Med Biol 24:35-43

17. Jeffery CM, Smith SV, Asad AH, Chan S, Price RI (2012) Routine production of copper-64 using $11.7 \mathrm{MeV}$ protons AIP Conf Proc 1509:84-90

18. Thieme S, Walther M, Pietzsch HJ, Henniger J, Preusche S, Mäding P, Steinbach J (2012) Module-assisted preparation of ${ }^{64} \mathrm{Cu}$ with high specific activity. Appl Radiat Isotop 70:602-608

19. Rajec P, Csiba V, Leporis M, Štefečka M, Losonczi Pataky E, Reich M, Ometáková J (2010) Preparation and characterization of nickel targets for cyclotron production of ${ }^{64} \mathrm{Cu}$. J Radioanal Nucl Chem 286:665-670

20. van der Meulen NP, Hasler R, Blanc A, Farkas R, Benešová M, Talip Z, Müller C, Schibli R (2019) Implementation of a new separation method to produce qualitatively improved ${ }^{64} \mathrm{Cu}$. J Label Comp Radiopharm 62:460-470

21. Manrique-Arias JC, Avila-Rodriguez MA (2014) A simple and efficient method of nickel electrodeposition for the cyclotron production of ${ }^{64} \mathrm{Cu}$. Appl Radiat Isotop 89:37-41

22. Xie Q, Zhu H, Wang F, Meng X, Ren Q, Xia C, Yang Z (2017) Establishing reliable $\mathrm{Cu}-64$ production process: from target plating to molecular specific tumor micro-PET imaging. Molecules 22:641-1-641-10 
23. Kim JY, Park H, Lee JC, Kim KM, Lee KC, Ha HJ, Choi TH, An GI, Cheon GJ (2009) A simple $\mathrm{Cu}-64$ production and its application of Cu-64 ATSM. Appl Radiat Isotop 67:1190-1194

24. Al Rayyes AH, Ailouti Y (2013) Production and quality control of ${ }^{64} \mathrm{Cu}$ from high current Ni target. World J Nucl Sci Technol 3:72-77

25. Ohya T, Nagatsu K, Suzuki H, Fukada M, Minegishi K, Hanyu M, Fukumura T, Zhang MR (2016) Efficient preparation of highquality ${ }^{64} \mathrm{Cu}$ for routine use. Nucl Med Biol 43:685-691

26. Ometáková J, Rajec P, Csiba V, Leporis M, Štefečka M, Vlk P, Galamboš M, Rosskopfova O (2012) Automated production of ${ }^{64} \mathrm{Cu}$ prepared by $18 \mathrm{MeV}$ cyclotron. J Radioanal Nucl Chem 293:217-222

27. Piel H, Qaim SM, Stöcklin G (1992) Excitation functions of (p, $\mathrm{xn}$ )-reactions on ${ }^{\text {nat }} \mathrm{Ni}$ and highly enriched ${ }^{62} \mathrm{Ni}$ : possibility of production of medically important radioisotope ${ }^{62} \mathrm{Cu}$ at a small cyclotron. Radiochim. Acta 57:1-5

28. Matarrese M, Bedeschi P, Scardaoni R, Sudati F, Savi A, Pepe A, Masiello V, Todde S, Gianolli L, Messa C, Fazio F (2010) Automated production of copper radioisotopes and preparation of high specific activity $\left[{ }^{64} \mathrm{Cu}\right] \mathrm{Cu}$-ATSM for PET studies. Appl Radiat Isotop 68:5-13

29. Cyclotron produced radionuclides: emerging positron emitters for medical applications: ${ }^{64} \mathrm{Cu}$ and ${ }^{124} \mathrm{I}(2016)$ IAEA radioisotopes and radiopharmaceuticals reports no. 1, IAEA, Vienna

30. Sadeghi M, Amiri M, Gholamzadeh Z, Rowshanfarzad P (2009) Nickel electrodeposition on copper substrate for cyclotron production of ${ }^{64} \mathrm{Cu}$. Radiochemistry 51:628-632

31. De Laeter JR, Böhlke JK, De Bièvre P, Hidaka H, Peiser HS, Rosman KJR, Taylor PDP (2003) Atomic weights of the elements: review 2000. Pure Appl Chem 75:683-800

32. Radford LL, Fernandez S, Beacham R, El Sayed R, Farkas R, Benešová M, Müller C, Lapi SE (2019) New ${ }^{55}$ Co-labeled albuminbinding folate derivatives as potential PET agents for folate receptor imaging. Pharmaceuticals 12:166-1-166-12

33. Mieszkowska M, Grdeń M (2021) Electrochemical deposition of nickel targets from aqueous electrolytes for medical radioisotopes production in accelerators. A review. J Solid State Electrochem 25:1699-1725

34. Di Bari GA (2001) Electrodeposition of nickel, in Schlesinger M, Paunovic M (Eds) Modern electroplating, Wiley, Hoboken

35. Dennis JK, Such TE (1993) Nickel and chromium plating. Woodhead, Cambridge

36. Burke P, Golovko O, Clark JC, Aigbirhio FI (2010) An automated method for regular productions of copper-64 for PET radiopharmaceuticals. Inorg Chim Acta 363:1316-1319

37. Zeisler SK, Pavan RA, Orzechowski J, Langlois R, Rodrigue S, van Lier JE (2003) Production of ${ }^{64} \mathrm{Cu}$ on the Sherbrooke TRPET cyclotron. J Radioanal Nucl Chem 257:175-177

38. Svedjehed J, Kutyreff CJ, Engle JW, Gagnon K (2020) Automated, cassette-based isolation and formulation of high-purity $\left[{ }^{61} \mathrm{Cu}\right] \mathrm{CuCl}_{2}$ from solid Ni targets. EJNMMI Radiopharm Chem 5:21-1-21-14

39. Streinz CC, Hartman AP, Motupally S, Weidner JW (1995) The effect of current and nickel nitrate concentration on the deposition of nickel hydroxide films. J Electrochem Soc 142:1084-1089

40. Hall DS, Lockwood DJ, Bock C, MacDougall BR (2015) Nickel hydroxides and related materials: a review of their structures, synthesis and properties. Proc R Soc A 471:20140792-1-20140792-65

41. Wohlfahrt-Mehrens M, Oesten R, Wilde P, Huggins RA (1996) The mechanism of electrodeposition and operation of $\mathrm{Ni}(\mathrm{OH})_{2}$ layers. Solid State Ionics 86-88:841-847

42. Ibrahim MAM (2006) Black nickel electrodeposition from a modified Watts bath. J Appl Electrochem 36:295-301

43. Mandich NV, Baudrand DW (2002) Troubleshooting electroplating installations: nickel sulfamate plating systems. Plat Surf Finish 89:68-76
44. Rebeles RA, Van den Winkel P, Hermanne A, Tárkányi F (2009) New measurement and evaluation of the excitation function of ${ }^{64} \mathrm{Ni}(\mathrm{p}, \mathrm{n})$ reaction for the production of ${ }^{64} \mathrm{Cu}$. Nucl Instr Met Phys Res B 267:457-461

45. Standardized high current solid targets for cyclotron production of diagnostic and therapeutic radionuclides (2004) Technical reports series no. 432, IAEA, Vienna

46. Oh CJ, Lee SO, Yang HS, Ha TJ, Kim MJ (2003) Selective leaching of valuable metals from waste printed circuit boards. J Air Waste Manag Assoc 53:897-902

47. Bilczuk D, Olvera OG, Asselin E (2016) Kinetic study of the dissolution of metallic nickel in sulphuric acid solutions in the presence of different oxidants. Can J Chem Eng 94:1872-1879

48. Daraban L, Rebeles RA, Hermanne A (2009) Study of the excitation function for the deuteron induced reaction on ${ }^{64} \mathrm{Ni}(\mathrm{d}, 2 \mathrm{n})$ for the production of the medical radioisotope ${ }^{64} \mathrm{Cu}$. Appl Radiat Isot 67:506-510

49. Geiger S, Cherevko S, Mayrhofer KJJ (2015) Dissolution of platinum in presence of chloride traces. Electrochim Acta 179:24-31

50. Shrestha BR, Tada E, Nishikataba A (2014) Effect of chloride on platinum dissolution. Electrochim Acta 143:161-167

51. Patil RS, Juvekar VA, Naik VM (2011) Oxidation of chloride ion on platinum electrode: dynamics of electrode passivation and its effect on oxidation kinetics. Ind Eng Chem Res 50:12946-12959

52. Saarinen T, Lindfors LE, Fugleberg S (1996) A study of a nickel hydroxide sulphate precipitate obtained during hydrogen reduction of nickel hydroxide slurries. Hydrometallurgy 43:129-142

53. Marikkannu KR, Surya Kala K, Paruthimal Kalaignan G, Vasudevan $\mathrm{T}$ (2008) Electroplating of nickel from acetate based bath - Hull Cell studies. Trans IMF 86:172-176

54. Šupicová M, Rozik R, Trnková L, Oriňáková R, Gálová M (2006) Influence of boric acid on the electrochemical deposition of $\mathrm{Ni}$. J Solid State Electrochem 10:61-68

55. Dávalos CE, López JR, Ruiz H, Méndez A, Antaño-López R, Trejo G (2013) Study of the role of boric acid during the electrochemical deposition of $\mathrm{Ni}$ in a sulfamate bath. Int J Electrochem Sci 8:9785-9800

56. Yin KM, Lin BT (1996) Effects of boric acid on the electrodeposition of iron, nickel and iron-nickel. Surf Coat Technol 78:205-210

57. Oriňáková R, Turoňová $\mathrm{A}$, Kladeková $\mathrm{D}$, Gálová $\mathrm{M}$, Smith RM (2006) Recent developments in the electrodeposition of nickel and some nickel-based alloys. J Appl Electrochem 36:957-972

58. Tsuru Y, Nomura M, Foulkes FR (2002) Effects of boric acid on hydrogen evolution and internal stress in films deposited from a nickel sulfamate bath. J Appl Electrochem 32:629-634

59. Ji J, Cooper WC, Dreisinger DB, Peters E (1995) Surface pH measurements during nickel electrodeposition. J Appl Electrochem 25:642-650

60. Ibrahim MAM, Al Radadi RM (2015) Role of glycine as a complexing agent in nickel electrodeposition from acidic sulphate bath. Int J Electrochem Sci 10:4946-4971

61. Skitał PM, Sanecki PT, Saletnik D, Kalembkiewicz J (2019) Electrodeposition of nickel from alkaline $\mathrm{NH}_{4} \mathrm{OH} / \mathrm{NH}_{4} \mathrm{Cl}$ buffer solutions. Trans Nonferrous Met Soc China 29:222-232

62. Wang J, Gabe DR, Hart AC, Crouch PC (2013) The chemistry of nickel electroplating solutions. Trans IMF 91:4-10

63. Aluker NL, Herrmann ME, YaM Suzdaltseva (2019) A spectrophotometric study of nitrate and nitrite salts and their aqueous solutions. Optics Spectr 127:991-996

64. Ershov BG, Panich NM (2018) Chemical and spectral behavior of nitric acid in aqueous sulfuric acid solutions: Absorption spectrum and molar absorption coefficient of nitronium ion. Spectrochim Acta A: Mol Biomol Spectr 188:179-182

65. Mohd Adli N, Zhang H, Mukherjee S, Wu G (2018) Reviewammonia oxidation electrocatalysis for hydrogen generation and fuel cells. J Electrochem Soc 165:J3130-J3147 
66. Le Vot S, Reyter D, Roué L, Bélanger D (2012) Electrochemical oxidation of $\mathrm{NH}_{3}$ on platinum electrodeposited onto graphite electrode. J Electrochem Soc 159:F91-F96

67. Gabe DR (1997) The role of hydrogen in metal electrodeposition processes. J Appl Electrochem 27:908-915

68. Popov KI, Djokić SS, Nikolić ND, Jović VD (2016) Morphology of electrochemically and chemically deposited metals. Springer

69. Grujicic D, Pesic B (2006) Electrochemical and AFM study of nickel nucleation mechanisms on vitreous carbon from ammonium sulfate solutions. Electrochim Acta 51:2678-2690

70. Hankin A, Kelsall GH (2012) Electrochemical recovery of nickel from nickel sulfamate plating effluents. J Appl Electrochem 42:629-643

71. Martí-Calatayud MC, García-Gabaldón M, Pérez-Herranz V, Ortega E (2011) Determination of transport properties of Ni(II) through a Nafion cation-exchange membrane in chromic acid solutions. J Membr Sci 379:449-458

72. Mech K (2017) Influence of organic ligands on electrodeposition and surface properties of nickel films. Surf Coat Technol 315:232-239

73. Petrova EV, Vorontsova MA, Manomenova VL, Rashkovich LN (2012) Some properties of aqueous solutions of $\alpha-\mathrm{NiSO}_{4} \cdot 6 \mathrm{H}_{2} \mathrm{O}$. Crystallogr Rep 57:579-584

74. Oriňáková R, Strečková M, Trnková L, Rozik R, Gálova M (2006) Comparison of chloride and sulphate electrolytes in nickel electrodeposition on a paraffin impregnated graphite electrode. $\mathbf{J}$ Electroanal Chem 594:152-159

75. Santana AIC, Díaz SL, Barcia OE, Mattos OR (2009) A kinetic study on nickel electrodeposition from sulfate acid solutions. II. Reaction modeling. J Electrochem Soc 156:D331-D335

76. Buffle J, Zhang Z, Startchev K (2007) Metal flux and dynamic speciation at (bio)interfaces. Part I: critical evaluation and compilation of physicochemical parameters for complexes with simple ligands and fulvic/humic substances. Environ. Sci Technol 41:7609-7620

77. Boubatra M, Azizi A, Schmerber G, Dinia A (2012) The influence of $\mathrm{pH}$ electrolyte on the electrochemical deposition and properties of nickel thin films. Ionics 18:425-432

78. Motoyama M, Fukunaka Y, Sakka T, Ogata YH (2006) Effect of surface $\mathrm{pH}$ on electrodeposited Ni films. J Electrochem Soc 153:C502-C508

79. Quaino P, Juarez F, Santos E, Schmickler W (2014) Volcano plots in hydrogen electrocatalysis - uses and abuses. Beilstein J Nanotechnol 5:846-854

80. Bao F, Kemppainen E, Dorbandt I, Bors R, Xi F, Schlatmann R, van de Krol R, Calnan S (2021) Understanding the hydrogen evolution reaction kinetics of electrodeposited nickel-molybdenum in acidic, near-neutral, and alkaline conditions. ChemElectroChem 8:195-208

81. Ďurovič M, Hnát J, Bouzek K (2021) Electrocatalysts for the hydrogen evolution reaction in alkaline and neutral media. A comparative review. J Power Sources 493:229708-1-229708-17

82. Pourbaix M (1974) Atlas of electrochemical equilibria in aqueous solutions. NACE, Houston

83. Pereiro I, Fomitcheva Khartchenko A, Petrini L, Kaigala GV (2019) Nip the bubble in the bud: a guide to avoid gas nucleation in microfluidics. Lab Chip 19:2296-2314

84. Meegoda JN, Hewage SA, Batagoda JH (2018) Stability of nanobubbles. Environ Eng Sci 35:1216-1227

85. Ruetschi P, Amlie RF (1966) Solubility of hydrogen in potassium hydroxide and sulfuric acid. Salting-out and hydration. J Phys Chem 70:718-723

86. Kiuchi D, Matsushima H, Fukunaka Y, Kuribayashi K (2006) Ohmic resistance measurement of bubble froth layer in water electrolysis under microgravity. J Electrochem Soc 153:E138-E143

87. Fujimura T, Hikima W, Fukunaka Y, Homma T (2019) Analysis of the effect of surface wettability on hydrogen evolution reaction in water electrolysis using micro-patterned electrodes. Electrochem Commun 101:43-46

88. Chen Y, Mojica F, Li G, Abel Chuang PY (2017) Experimental study and analytical modeling of an alkaline water electrolysis cell. Int J Energy Res 1-9

89. Briggs GWD, Fleischmann M (1966) Anodic deposition of $\mathrm{NiOOH}$ from nickel acetate solutions at constant potential. Trans Faraday Soc 62:3217-3228

90. Sanli AE, Aytaç A (2012) Electrochemistry of the nickel electrode as a cathode catalyst in the media of acidic peroxide for application of the peroxide fuel cell. ECS Trans 42:3-22

91. Bagotzky VS, Shumilova NA, Samoilov GP, Khrushcheva EI (1972) Electrochemical oxygen reduction on nickel electrodes in alkaline solutions-II. Electrochim Acta 17:1625-1635

92. Hothersall AW, Hammond RAF (1934) The effect of oxidising agents on nickel deposition. I. Hydrogen peroxide and nickel nitrate. Trans Faraday Soc 30:1079-1094

93. Du T, Vijayakumar A, Sundaram KB, Desai V (2004) Chemical mechanical polishing of nickel for applications in MEMS devices. Microel Eng 75:234-241

94. Nicoll WD, Smith AF (1955) Stability of dilute alkaline solutions of hydrogen peroxide. Ind Eng Chem 47:2548-2554

95. Sigel H, Wyss K, Waldmeier P, Griesser R (1974) Metal ions and hydrogen peroxide. XXIX. On the kinetics and mechanism of the catalase-like activity of nickel(II) and nickel(II)-amine complexes. J Coord Chem 3:235-247

96. Greene GU (1939) The rate of decomposition of hydrogen peroxide in nickel sulfate plating baths. Trans Electrochem Soc 76:391-400

97. Carriazo JG, Bossa-Benavides LF, Castillo E (2012) Catalytic activity of transition metals in the hydrogen peroxide decomposition. Quím Nova 35:1101-1106

98. Gupta BL (1973) Microdetermination techniques for $\mathrm{H}_{2} \mathrm{O}_{2}$ in irradiated solutions. Microchem J 18:363-374

99. Burns JM, Cooper WJ, Ferry JL, King DW, DiMento BP, McNeill K, Miller CJ, Miller WL, Peake BM, Rusak SA, Rose AL, Waite TD (2012) Methods for reactive oxygen species (ROS) detection in aqueous environments. Aquat Sci 74:683-734

100. Wolff SP (1994) Ferrous ion oxidation in presence of ferric ion indicator xylenol orange for measurement of hydroperoxides. Meth Enzymology 233:182-189

101. Deiana L, Carru C, Pes G, Tadolini B (1999) Spectrophotometric measurement of hydroperoxides at increased sensitivity by oxidation of $\mathrm{Fe}^{2+}$ in the presence of xylenol orange. Free Radic Res Sep 31:237-244

102. Dunford HB (2002) Oxidations of iron(II)/(III) by hydrogen peroxide: from aquo to enzyme. Coord Chem Rev 233-234:311-318

103. Le Truong G, De Laat J, Legube B (2004) Effects of chloride and sulfate on the rate of oxidation of ferrous ion by $\mathrm{H}_{2} \mathrm{O}_{2}$. Water Res 38:2384-2394

104. Barbusiński K (2009) Fenton reaction - controversy concerning the chemistry. Ecol Chem Eng 16:347-358

105. Aziz HA, Abu Amr SS (2019) Advanced oxidation processes (AOPs) in water and wastewater treatment. IGI Global, Hershey

106. Klassen NV, Marchington D, McGowan HCE (1994) $\mathrm{H}_{2} \mathrm{O}_{2}$ Determination by the $\mathrm{I}_{3}{ }^{-}$method and by $\mathrm{KMnO}_{4}$ titration. Anal Chem 66:2921-2925

107. Gimeno MP, Mayoral MC, Andrés JM (2013) A potentiometric titration for $\mathrm{H}_{2} \mathrm{O}_{2}$ determination in the presence of organic compounds. Anal Meth 5:1510-1514

108. Wang C, Zhang S, Yuji S, Zhang Z (2014) Analysis of a complex produced in the Fenton oxidation process. Water Sci Technol 69:1115-1119

109. Gil-Lozano C, Davila AF, Losa-Adams E, Fairén AG, GagoDuport L (2017) Quantifying Fenton reaction pathways 
driven by self-generated $\mathrm{H}_{2} \mathrm{O}_{2}$ on pyrite surfaces. Sci Rep 7:43703-1-43703-11

110. Perrin DD (1959) Spectrophotometric determination of iron as ferric acetate complex. Anal Chem 31:1181-1182

111. Reiss W, Hazel JF, McNabb WM (1952) Application of absorption spectrum of ferric acetate complex to determination of iron. Anal Chem 24:1646-1648

112. Ishibashi M, Sigematsu T, Yamamoto Y, Tabushi M, Kitayama M (1957) Ultraviolet spectrophotometric determination of iron (III) as acetato-complex. Bul Inst Chem Res Kyoto Univ 35:6-15

113. Driscoll OJ, Hafford-Tear CH, McKeown P, Stewart JA, Kociok-Köhn G, Mahon MF, Jones MD (2019) The synthesis, characterisation and application of iron(III)-acetate complexes for cyclic carbonate formation and the polymerisation of lactide. Dalton Trans 48:15049-15058

114. Zhao X, Zhang T, Zhou Y, Liu D (2007) Preparation of peracetic acid from hydrogen peroxide. Part I: Kinetics for peracetic acid synthesis and hydrolysis. J Mol Catal A: Chem 271:246-252

115. Zhang Z, Liao L, Wang X, Xie W, Guo D (2020) Development of a novel chemical mechanical polishing slurry and its polishing mechanisms on a nickel alloy. Appl Surf Sci 506:144670-1-144670-9

116. Nicholls D (1973) The chemistry of iron, cobalt and nickel. Pergamon, Oxford

117. Kerfoot DGE (2012) Nickel. In: Ullmann's encyclopedia of industrial chemistry, Wiley, Weinheim

118. Hernández N, Moreno R, Sánchez-Herencia AJ, Fierro JLG (2005) Surface behavior of nickel powders in aqueous suspensions. J Phys Chem B 109:4470-4474

119. Katsounaros I, Schneider WB, Meier JC, Benedikt U, Biedermann PU, Auer AA, Mayrhofer KIJ (2012) Hydrogen peroxide electrochemistry on platinum: towards understanding the oxygen reduction reaction mechanism. Phys Chem Chem Phys 14:7384-7391

120. Gulaboski R, Mirčeski V, Kappl R, Hoth M, Bozem M (2019) Review-quantification of hydrogen peroxide by electrochemical methods and electron spin resonance spectroscopy. J Electrochem Soc 166:G82-G101

121. Sitta E, Feliu JM (2014) The role of $\mathrm{PtOH}$ on $\mathrm{H}_{2} \mathrm{O}_{2}$ interactions with platinum surfaces in an electrochemical environment. ChemElectroChem 1:55-58

122. Strbac $\mathrm{S}$ (2011) The effect of $\mathrm{pH}$ on oxygen and hydrogen peroxide reduction on polycrystalline Pt electrode. Electrochim Acta 56:1597-1604

123. Lasia A, Rami A (1990) Kinetics of hydrogen evolution on nickel electrodes. J Electroanal Chem 294:123-141

124. Bianchi G, Mazza F, Mussini T (1962) Catalytic decomposition of acid hydrogen peroxide solutions on platinum, iridium, palladium and gold surfaces. Electrochim Acta 7:457-473

125. Hoffmann MR, Edwards JO (1975) Kinetics of the oxidation of sulfite by hydrogen peroxide in acidic solution. J Phys Chem 79:2096-2098

126. Maaß F, Elias H, Wannowius KJ (1999) Kinetics of the oxidation of hydrogen sulfite by hydrogen peroxide in aqueous solution: ionic strength effects and temperature dependence. Atm Env 33:4413-4419

127. McKee DW (1969) Catalytic decomposition of hydrogen peroxide by metals and alloys of the platinum group. J Catal $14: 355-364$

Publisher's Note Springer Nature remains neutral with regard to jurisdictional claims in published maps and institutional affiliations. 